\title{
Fat and fatty acid content and composition of forages: A meta-analysis
}

\author{
F. Glasser ${ }^{\mathrm{a}, \mathrm{b}}$, M. Doreau ${ }^{\mathrm{a}, \mathrm{b}, *}, \mathrm{G}$. Maxin ${ }^{\mathrm{a}, \mathrm{b}}$, R. Baumont ${ }^{\mathrm{a}, \mathrm{b}}$ \\ a INRA, UMR1213 Herbivores, F-63122 Saint-Genès-Champanelle, France \\ b Clermont Université, VetAgro Sup, UMR Herbivores, BP 10448, F-63000 Clermont-Ferrand, France
}

\section{A R T I C L E I N F O}

\section{Article history:}

Received 23 May 2012

Received in revised form 20 June 2013

Accepted 22 June 2013

\section{Keywords:}

Fat

Fatty acid

Forage

Silage

Hay

Linolenic acid

\begin{abstract}
A B S T R A C T
Forages, through the amount and composition of their fatty acids (FA), and because they represent a major part of ruminant diets, can help improve the nutritional quality of milk and meat. However, no comprehensive dataset is available to estimate fat and FA content and composition of forages. This study used the available data on fat and FA content and composition of forages to (i) compute mean composition values for the main forages, and (ii) estimate the influence of forage conservation, cultivation and harvest conditions on fat and FA content and composition. We report mean values for the main forage species in the form of fresh forage, silage or hay. The main factor influencing fat and FA composition was vegetation stage of forage at harvest (estimated by the month of harvest or regrowth interval). Compared with fresh forage at harvest, wilting or drying forages (especially in bad drying conditions) altered their FA, whereas unwilted silage, the use of ensiling additives and $\mathrm{N}$ fertilization had only minor effects. The differences between grass (except corn) and legume species were lower than those induced by vegetation stage and wilting or drying. We gave equations to estimate the effects of these factors and thus refine the estimation of the FA content and composition of the forages. Total FA content and proportion of linolenic acid were positively related to crude protein, and negatively related to fiber content of the forages.
\end{abstract}

(c) 2013 Elsevier B.V. All rights reserved.

\section{Introduction}

Forages form a major part of dairy cows' diets in most farming systems, and sometimes contain significant amounts of fat and polyunsatured fatty acids (FA). Diets based on pasture and grass silage can thus improve the nutritional quality of milk and meat by shifting their FA composition toward less saturated FA and more polyunsatured FA, especially omega-3 FA (Dewhurst et al., 2006). For example, these diets can provide milk that is as rich in linolenic acid (C18:3 $n$-3) as linseedsupplemented diets and lower in trans-FA (Dewhurst et al., 2006; Chilliard et al., 2007). Several empirical models have been developed to describe relationships between dietary FA and FA digestion (Glasser et al., 2008b; Schmidely et al., 2008) or milk FA composition (Glasser et al., 2008a). To optimize diet composition for a target milk FA composition, we need to know the FA content and composition of the dietary feedstuffs. Mean values for fat content and FA composition of concentrate feedstuffs (cereals, oilseeds and their products) are available in feed tables (e.g. Sauvant et al., 2004). However, to the best of our knowledge, no quantitative analysis of a comprehensive dataset is available for forages, despite a significant number of publications dedicated to the FA composition of forages, or simply reporting FA composition of some forages used in

\footnotetext{
Abbreviations: ADF, acid detergent fiber; CP, crude protein; DM, dry matter; FA, fatty acid; OM, organic matter; NDF, neutral detergent fiber.

* Corresponding author at: INRA, UMR1213 Herbivores, F-63122 Saint-Genès-Champanelle, France. Tel.: +33 473624113 ; fax: +33 473624273.

E-mail addresses: michel.doreau@clermont.inra.fr, doreau@clermont.inra.fr (M. Doreau).
} 
experiments. The nature and composition of forages influence FA metabolism in the rumen (Buccioni et al., 2012); it is thus of interest to study the factors that modify FA in forages. Fuller knowledge of the factors that influence the FA content and composition of forages could help farmers to optimize cultivation and harvest conditions and thereby improve the quality of their forages (Khan et al., 2012).

This study uses the available data for fat and FA content and composition of forages to (i) compute mean composition values for the main forages and (ii) estimate the influence of forage conservation, cultivation and harvest conditions on fat and FA content and composition.

\section{Materials and methods}

\subsection{Database building}

A database was built from systematic web searches and examination of bibliographic references that included all publications dated post-1970 dealing with the effects of various factors on the FA composition of forages. Publications were included when at least two of the following measurements were reported (or computable from the reported data): FA composition of forages (as g/100 g of total FA or dry matter [DM]), total FA content (in $\mathrm{g} / \mathrm{kg} \mathrm{DM}$ ) and fat content (g/kg DM). This focused database comprised a total of 58 publications (Appendix 1) and two unpublished experiments by our laboratory (INRA, UMR1213 Herbivores, Saint-Genès-Champanelle, France).

To estimate the influence of forage conservation and cultivation or harvest conditions on fat and FA composition, the database was split into four sub-databases according to the variation factor studied: 26 publications studied the effect of conservation (fresh forages compared with ensiled, wilted, hay, etc.) (250 forages), 32 studied the effect of vegetation stages (comparing different dates of harvest or regrowth intervals, numbers of cuts, etc.) (281 forages); 9 studied the effect of silage additives (68 forages), and 5 the effect of fertilization (50 forages). Thirteen publications studied other effects and were not included in the four sub-databases.

For the determination of mean composition values for the main forages, this database was completed with various forage analysis data extracted from a non-focused database comprising 136 publications dealing with the digestion of FA in ruminants or relationships between dietary FA and milk FA (Appendix 2).

The study focused on the five main FA, which cover more than $95 \mathrm{~g} / 100 \mathrm{~g}$ of total FA: palmitic, stearic, oleic, linoleic and linolenic acids, referred to as 16:0, 18:0,18:1, 18:2 and 18:3, respectively. The main analytical methods used for fat determination in the publications were ether extraction (53\% of total publications, with either petroleum ether or diethyl ether), acid ether extraction (ether extraction preceded by $\mathrm{HCl}$ hydrolysis: 16\% of total publications), chloroform-methanol extraction (Folch et al., 1957: 10\% of total publications) and hexane extraction (6\% of total publications). For FA determination, the main methods were one-step methylation (Sukhija and Palmquist, 1988) for 53\% of total publications, chloroform-methanol followed by $\mathrm{NaOH}-$ methanol (14\% of total publications), and chloroform-methanol followed by other procedures (13\% of total publications).

\subsection{Data cleansing}

Once the databases had been built, we proceeded to cleanse the data: when the number of data included in a metaanalysis is limited, the atypical data has a high leverage effect on the resulting means, equations or models. To partly overcome this limit, we opted to exclude the statistical outliers: if Q1 is the first quartile and Q3 the third quartile, data below "Q1 - $1.5 \times(\mathrm{Q} 3-\mathrm{Q} 1)$ " or above "Q3+1.5×(Q3 - Q1)" were considered as outliers, a criterion used to identify outliers in boxplots (Tukey, 1977).

Some publications have reported the effect of one particular factor on several cultivars of the same species, leading to an inflation of data for these publications and a high weight in the resulting analysis. In this case, only the means of all the cultivars were used in the analyses, or only one cultivar was selected that exhibited average values for the species. In the publications comparing the composition of a fresh forage and the same forage ensiled with different additives, only the silage with no additive was used in the comparison. The forages that were only wilted without ensiling, were not considered, as they are of no practical use.

\subsection{Statistical analyses}

The publications were very diverse in terms of factor studied, forage species and conservation methods, and of analytical methods used for fat and FA determination. When all these factors were simultaneously taken into account, very small clusters of data resulted, often extracted from only 1 or 2 publications, and so very likely subject to publication bias. To limit this bias, we chose to favor global approaches, pooling several plant species, or several analytical methods, or several modalities, so as to obtain at least 10 data items per pool and thus more robust estimates of the effects studied. Hence some differences are probably disregarded, but the analyses reported are based on a larger dataset, and so less likely to be biased by publication effects. 
For the computation of mean values for the main forage categories, we computed the means and SD, pooling data to have at least 10 forages per category (due to missing values, not all criteria had 10 data items; we kept only those criteria for which more than 3 data items were available).

For the estimation of the total FA content of the forages from their fat content, GLM models (SAS, 2008) were used on all the data reporting both fat content and total FA content for the same forage. The dependent variable was total FA content $(\mathrm{g} / \mathrm{kg}$ DM); the independent variables were fat content and other chemical composition criteria available in the publications. Several factors were also tested in these models of total FA content, either as simple effects or in interaction with fat content: analytical method, forage species, etc. For all the other analyses (effect of selected factors on forage composition), we took a within-forage approach, comparing the effect of a factor (conservation, cultivation conditions, etc.) applied to the same forage within the same publication (Sauvant et al., 2008). For these models, data were encoded to identify each forage and its counterparts, varying only in the factor of interest, e.g. haymaking the same code was used for one fresh forage and the corresponding hay; for the vegetation stages the same code was used for one forage harvested at different stages. For the effects of qualitative factors (haymaking, ensiling and silage additive), we adjusted GLM models (SAS, 2008) of the composition of the treated forage (conserved or with additive) according to the composition of the untreated forage (fresh or without additive). For the effect of continuous variables (chemical composition, cutting date or regrowth intervals for vegetation stages, $\mathrm{N}$ fertilization), mixed models (SAS, 2008) were used, including a random forage effect (represented by the above codes, to account for the variance between forages). For the effect of cutting date, successive cutting dates for the same forage were considered as repeated measurements, with an autoregressive covariance structure. For all the statistical analyses, the significance threshold was set at $\mathrm{P}<0.05$.

\section{Results}

\subsection{Mean composition of the main forage categories}

We compiled all the data available in the overall database to obtain mean values and variability of the FA and chemical composition of the main forage categories. The resulting values are given in Table 1 for single-species grass forages, in Table 2 for legumes and corn silage, and in Table 3 for multi-species forages.

For orchard grass (Table 1), there was a group of hays with very low 18:3 contents, which we named "low-quality hays" (in some instances, the conditions of haymaking were mentioned in the publications, reporting wet weather or a long duration of drying). These low-quality hays had a mean $18: 3$ content of $28.1 \mathrm{~g} / 100 \mathrm{~g}$ total FA, against 51.8 for the fresh orchardgrass. There were only two data items reporting the content of 18:3 in "standard" orchardgrass hays (50.2 and $41.6 \mathrm{~g} / 100 \mathrm{~g})$, with a mean of $45.9 \mathrm{~g} / 100 \mathrm{~g}$ total FA. For ryegrass, only fresh ryegrass and ryegrass silage are reported in Table 1 , because there were fewer than 10 data items for ryegrass hay in the database.

Alfalfa (Table 2) was characterized by a large decrease in 18:3 content by haymaking, the 18:3 content of most hays being almost half that of fresh alfalfa. Only two data items, corresponding to pelleted alfalfa, exhibited 18:3 contents similar to those of the fresh forage. Good drying conditions could thus ensure the preservation of this FA. Some alfalfa hays, originating in publications from South Dakota State University, Brookings (e.g. Casper et al., 1988, 1990; Dhiman et al., 1999; Chichlowski et al., 2005), were very low in total FA ( $<10 \mathrm{~g} / \mathrm{kg} \mathrm{DM})$ and high in 16:0 ( $>30 \mathrm{~g} / 100 \mathrm{~g}$ total FA) and 18:0. However, they did not differ significantly from the other alfalfa hays for the other components. Whether this was an effect of the forages themselves or of sample handling or analytical methods remains unclear.

For red clover, all the conserved forages (hay and silages) were pooled to obtain enough data: there was no significant difference (based on the few data items available) between these two conservation methods.

Within corn silages, the contents of 18:2 and 18:3 ranged widely, but were related to their chemical composition. The content of 18:2 was related to the neutral detergent fiber (NDF) content of the corn silage according to the equation:

$18: 2(\mathrm{~g} / 100 \mathrm{~g}$ total FA $)=97.8-0.124 \mathrm{NDF}(\mathrm{g} / \mathrm{kg} \mathrm{DM})$

$\left(n=18, \quad R^{2}=0.42, \quad \operatorname{RMSE}=7.1\right)$.

The content of 18:3 was related to the DM content of the corn silage by:

$18: 3(\mathrm{~g} / 100 \mathrm{~g}$ total FA $)=15.6-0.0285 \mathrm{DM}(\mathrm{g} / \mathrm{kg}$ fresh weight $)$

$\left(n=18, \quad R^{2}=0.56, \quad\right.$ RMSE $\left.=1.7\right)$.

The multi-species forages exhibited broad variability: they were referred to as "grass", "pasture" or various mixes of grass and legumes (clovers and alfalfa), most often poorly characterized regarding their species composition, vegetation stages, etc. Given this heterogeneity, we opted to pool all the data corresponding to multi-species forages. Table 3 presents the mean values according to the conservation: fresh, silage or hay, with an additional category, "low-quality hay", defined as

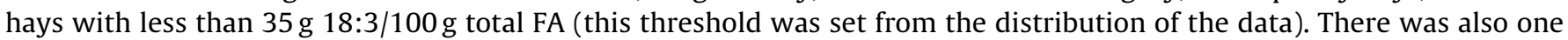
silage with a very low 18:3 content (bromegrass and alfalfa silage, Wiesen et al., 1990). 
Table 1

Single-species grass forages: fatty acid (in g/100 g total FA ${ }^{\mathrm{a}}$ ) and chemical composition (in $\mathrm{g} / \mathrm{kg}_{\mathrm{g}} \mathrm{DM} \mathrm{a}^{\mathrm{a}}$ ). The values are presented as means $\pm \mathrm{SD}$, number of observations. Only cells with more than 3 observations are reported.

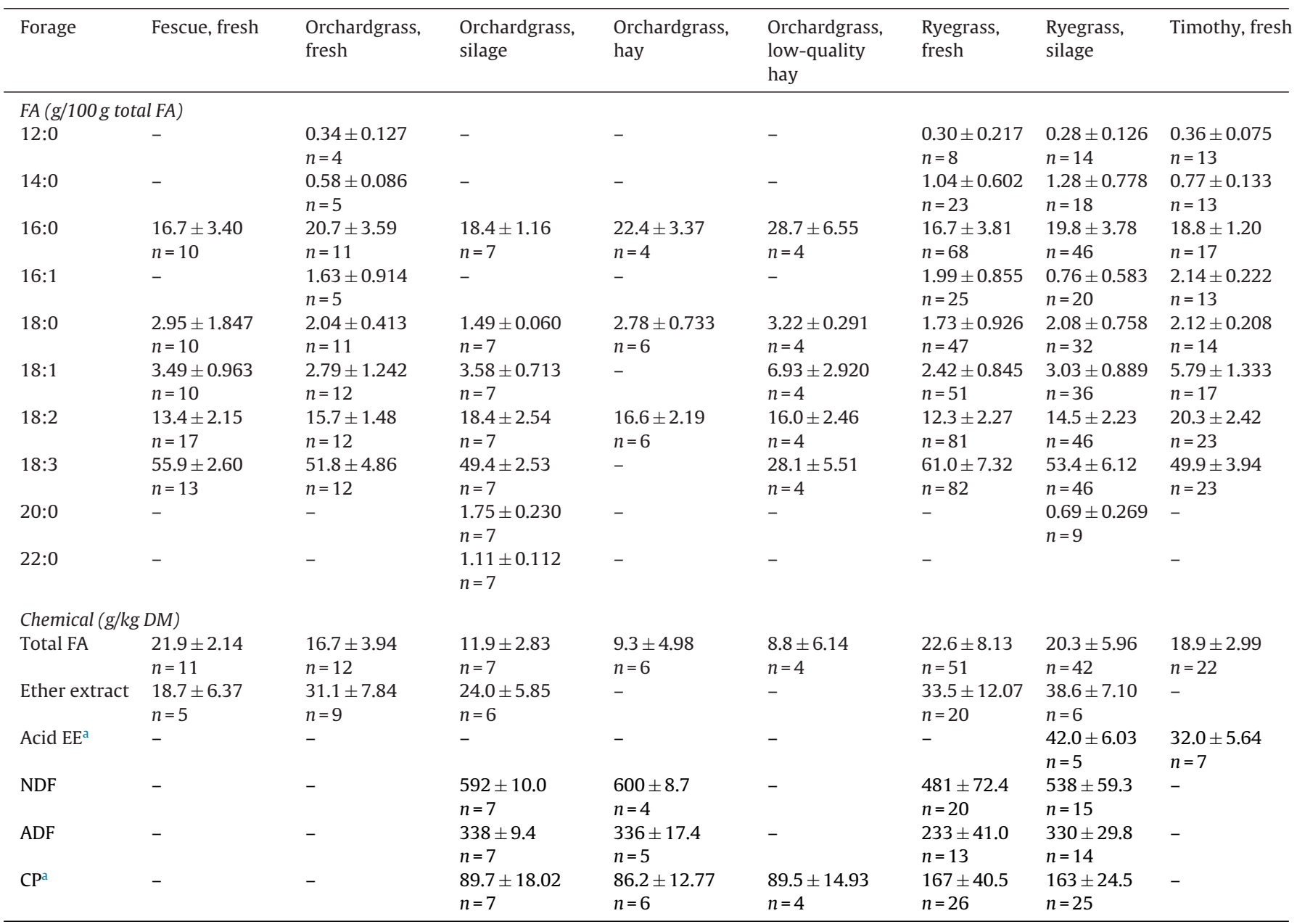

${ }^{a}$ FA, fatty acids; DM, dry matter; EE, ether extract; CP, crude protein.

\subsection{Relationships between total FA content and fat content}

From this point, all analyses were made on a within-forage basis, i.e. the relationships and comparisons were established on the same forage from the same publication. In the literature, forages are sometimes characterized by their fat content and FA composition, without their total FA content. It would thus be useful to be able to estimate total FA content from fat content of the forage. To adjust models of total FA content from fat content, we studied corn silage and the other forages separately. For corn silage, after the removal of some outliers $(n=4)$, there were 13 data items with both total FA and fat contents, with fat content ranging between 25.0 and $37.5 \mathrm{~g} / \mathrm{kg}$ DM. There was a negative relationship between total FA and fat:

$$
\begin{aligned}
& \text { Total FA }(\mathrm{g} / \mathrm{kg} \mathrm{DM})=33.5-0.347 \mathrm{fat}(\mathrm{g} / \mathrm{kg} \mathrm{DM}) \\
& \left(n=13, \quad R^{2}=0.43, \quad \text { RMSE }=1.3\right) .
\end{aligned}
$$

For the other forages, various models of total FA content were tested, including the effects of fat content, other chemical characteristics (NDF, acid detergent fiber (ADF), crude protein (CP), etc.), and the effects of the species, botanical family, conservation, method used to determine the fat content, and various interactions between these factors. The best model was valid across all species and depended on fat content, NDF content, conservation and fat determination method:

$$
\text { Total FA }(\mathrm{g} / \mathrm{kg} \mathrm{DM})=28.0+\Delta_{\text {conserv }}+\Delta_{\text {method }}+0.21 \text { fat }-0.035 \mathrm{NDF}(\text { all in } \mathrm{g} / \mathrm{kg} \mathrm{DM}),
$$

with $\Delta_{\text {conserv }}=1.3$ for fresh, -2.5 for hay and 1.2 for silage; $\Delta_{\text {method }}=0.8$ for ether extract, -1.8 for hexane, 2.9 for Folch and -1.9 for acid ether extract $\left(n=57, R^{2}=0.61\right.$, RMSE $=3.6$ ).

On this dataset, fat and NDF contents ranged between 14.5 and $52.0 \mathrm{~g} / \mathrm{kg}$ DM, and 394 and $637 \mathrm{~g} / \mathrm{kg}$ DM respectively. The effect of the botanical family (grasses or legumes) was not significant in this model.

The effect of the fat determination method on the fat content value was difficult to assess, because very few publications were available that compared different methods on the same forage. The difference between fat content ( $\mathrm{g} / \mathrm{kg}$ DM) measured 
Table 2

Legumes and corn silage: fatty acid ( $\mathrm{g} / 100 \mathrm{~g}$ total $\left.\mathrm{FA}^{\mathrm{a}}\right)$ and chemical composition $\left(\mathrm{g} / \mathrm{kg} \mathrm{DM}^{\mathrm{a}}\right)$. The values are presented as means $\pm \mathrm{SD}$, number of observations. Only cells with more than 3 observations are reported.

\begin{tabular}{|c|c|c|c|c|c|c|c|c|}
\hline Forage & $\begin{array}{l}\text { Alfalfa, } \\
\text { fresh }\end{array}$ & $\begin{array}{l}\text { Alfalfa, } \\
\text { silage }\end{array}$ & Alfalfa, hay & $\begin{array}{l}\text { Red clover, } \\
\text { fresh }\end{array}$ & $\begin{array}{l}\text { Red clover, hay } \\
\text { or silage }\end{array}$ & $\begin{array}{l}\text { White clover, } \\
\text { fresh }\end{array}$ & $\begin{array}{l}\text { White clover, } \\
\text { wilted silage }\end{array}$ & Corn, silage \\
\hline \multicolumn{9}{|c|}{$F A(\mathrm{~g} / 100 \mathrm{~g}$ total $F A)$} \\
\hline $12: 0$ & $\begin{array}{l}0.94 \pm 0.948 \\
n=5\end{array}$ & $\begin{array}{l}1.23 \pm 0.746 \\
n=5\end{array}$ & $\begin{array}{l}0.93 \pm 1.165 \\
n=8\end{array}$ & $\begin{array}{l}0.20 \pm 0.157 \\
n=10\end{array}$ & $\begin{array}{l}0.17 \pm 0.152 \\
n=8\end{array}$ & $\begin{array}{l}0.18 \pm 0.124 \\
n=5\end{array}$ & - & $\begin{array}{l}0.35 \pm 0.164 \\
n=14\end{array}$ \\
\hline 14:0 & $\begin{array}{l}1.41 \pm 0.947 \\
n=6\end{array}$ & $\begin{array}{l}1.30 \pm 0.830 \\
n=6\end{array}$ & $\begin{array}{l}2.03 \pm 1.295 \\
n=18\end{array}$ & $\begin{array}{l}0.77 \pm 0.459 \\
n=13\end{array}$ & $\begin{array}{l}1.06 \pm 0.583 \\
n=10\end{array}$ & $\begin{array}{l}1.33 \pm 0.857 \\
n=7\end{array}$ & - & $\begin{array}{l}0.39 \pm 0.235 \\
n=27\end{array}$ \\
\hline $16: 0$ & $\begin{array}{l}23.2 \pm 2.21 \\
n=7\end{array}$ & $\begin{array}{l}24.4 \pm 2.79 \\
n=11\end{array}$ & $\begin{array}{l}29.9 \pm 9.03 \\
n=21\end{array}$ & $\begin{array}{l}18.0 \pm 3.53 \\
n=21\end{array}$ & $\begin{array}{l}19.7 \pm 3.39 \\
n=30\end{array}$ & $\begin{array}{l}15.3 \pm 2.35 \\
n=10\end{array}$ & $\begin{array}{l}16.1 \pm 2.09 \\
n=11\end{array}$ & $\begin{array}{l}15.9 \pm 2.05 \\
n=40\end{array}$ \\
\hline $16: 1$ & $\begin{array}{l}2.29 \pm 1.109 \\
n=6\end{array}$ & $\begin{array}{l}2.07 \pm 0.819 \\
n=8\end{array}$ & $\begin{array}{l}1.51 \pm 1.606 \\
n=15\end{array}$ & $\begin{array}{l}1.51 \pm 1.029 \\
n=13\end{array}$ & $\begin{array}{l}0.77 \pm 0.833 \\
n=8\end{array}$ & $\begin{array}{l}2.04 \pm 0.617 \\
n=9\end{array}$ & - & $\begin{array}{l}0.41 \pm 0.280 \\
n=24\end{array}$ \\
\hline $18: 0$ & $\begin{array}{l}4.07 \pm 0.693 \\
n=7\end{array}$ & $\begin{array}{l}3.71 \pm 0.641 \\
n=10\end{array}$ & $\begin{array}{l}4.59 \pm 1.274 \\
n=20\end{array}$ & $\begin{array}{l}2.99 \pm 0.997 \\
n=20\end{array}$ & $\begin{array}{l}2.83 \pm 0.660 \\
n=23\end{array}$ & $\begin{array}{l}2.02 \pm 0.617 \\
n=11\end{array}$ & $\begin{array}{l}2.32 \pm 0.614 \\
n=6\end{array}$ & $\begin{array}{l}2.32 \pm 0.676 \\
n=39\end{array}$ \\
\hline $18: 1$ & $\begin{array}{l}4.68 \pm 2.235 \\
n=7\end{array}$ & $\begin{array}{l}3.00 \pm 0.631 \\
n=9\end{array}$ & $\begin{array}{l}4.81 \pm 1.342 \\
n=19\end{array}$ & $\begin{array}{l}3.90 \pm 1.988 \\
n=20\end{array}$ & $\begin{array}{l}3.38 \pm 1.245 \\
n=25\end{array}$ & $\begin{array}{l}3.09 \pm 1.171 \\
n=12\end{array}$ & $\begin{array}{l}2.81 \pm 1.108 \\
n=6\end{array}$ & $\begin{array}{l}21.4 \pm 4.02 \\
n=44\end{array}$ \\
\hline $18: 2$ & $\begin{array}{l}19.9 \pm 2.39 \\
n=7\end{array}$ & $\begin{array}{l}18.2 \pm 2.60 \\
n=10\end{array}$ & $\begin{array}{l}17.8 \pm 2.79 \\
n=20\end{array}$ & $\begin{array}{l}19.8 \pm 2.52 \\
n=22\end{array}$ & $\begin{array}{l}18.7 \pm 2.67 \\
n=31\end{array}$ & $\begin{array}{l}16.5 \pm 2.37 \\
n=13\end{array}$ & $\begin{array}{l}15.2 \pm 1.86 \\
n=11\end{array}$ & $\begin{array}{l}45.8 \pm 7.89 \\
n=44\end{array}$ \\
\hline $18: 3$ & $\begin{array}{l}41.7 \pm 5.81 \\
n=7\end{array}$ & $\begin{array}{l}32.2 \pm 7.70 \\
n=11\end{array}$ & $\begin{array}{l}22.6 \pm 8.19 \\
n=22\end{array}$ & $\begin{array}{l}49.0 \pm 9.11 \\
n=22\end{array}$ & $\begin{array}{l}46.9 \pm 8.85 \\
n=31\end{array}$ & $\begin{array}{l}58.0 \pm 5.51 \\
n=11\end{array}$ & $\begin{array}{l}59.0 \pm 3.88 \\
n=11\end{array}$ & $\begin{array}{l}5.04 \pm 2.418 \\
n=42\end{array}$ \\
\hline $20: 0$ & - & - & $\begin{array}{l}1.20 \pm 0.595 \\
n=10\end{array}$ & $\begin{array}{l}0.93 \pm 0.498 \\
n=6\end{array}$ & $\begin{array}{l}1.01 \pm 0.337 \\
n=15\end{array}$ & - & - & $\begin{array}{l}0.74 \pm 0.392 \\
n=12\end{array}$ \\
\hline $22: 0$ & - & - & $\begin{array}{l}1.92 \pm 0.906 \\
n=9\end{array}$ & $\begin{array}{l}1.09 \pm 0.254 \\
n=5\end{array}$ & $\begin{array}{l}1.04 \pm 0.251 \\
n=13\end{array}$ & - & - & $\begin{array}{l}0.40 \pm 0.251 \\
n=15\end{array}$ \\
\hline $24: 0$ & - & - & $\begin{array}{l}1.65 \pm 1.359 \\
n=8\end{array}$ & $\begin{array}{l}1.26 \pm 0.201 \\
n=4\end{array}$ & $\begin{array}{l}1.34 \pm 0.465 \\
n=6\end{array}$ & - & - & $\begin{array}{l}0.60 \pm 0.410 \\
n=11\end{array}$ \\
\hline \multicolumn{9}{|c|}{ Chemical (g/kg DM) } \\
\hline Total FA & $\begin{array}{l}17.7 \pm 2.88 \\
n=7\end{array}$ & $\begin{array}{l}19.7 \pm 3.78 \\
n=9\end{array}$ & $\begin{array}{l}12.0 \pm 5.71 \\
n=15\end{array}$ & $\begin{array}{l}22.8 \pm 8.23 \\
n=20\end{array}$ & $\begin{array}{l}19.1 \pm 6.83 \\
n=31\end{array}$ & $\begin{array}{l}30.9 \pm 8.02 \\
n=11\end{array}$ & $\begin{array}{l}26.6 \pm 5.37 \\
n=11\end{array}$ & $\begin{array}{l}24.0 \pm 3.24 \\
n=27\end{array}$ \\
\hline Ether Extract & - & - & $\begin{array}{l}19.4 \pm 7.17 \\
n=13\end{array}$ & - & $\begin{array}{l}27.0 \pm 4.40 \\
n=7\end{array}$ & - & - & $\begin{array}{l}31.5 \pm 4.36 \\
n=17\end{array}$ \\
\hline Acid $\mathrm{EE}^{\mathrm{a}}$ & - & - & $\begin{array}{l}27.6 \pm 6.68 \\
n=7\end{array}$ & - & - & - & - & $\begin{array}{l}34.3 \pm 4.44 \\
n=7\end{array}$ \\
\hline NDF & - & $\begin{array}{l}447 \pm 43.0 \\
n=4\end{array}$ & $\begin{array}{l}488 \pm 53.1 \\
n=12\end{array}$ & $\begin{array}{l}366 \pm 66.9 \\
n=10\end{array}$ & $\begin{array}{l}423 \pm 60.6 \\
n=19\end{array}$ & - & - & $\begin{array}{l}418 \pm 46.1 \\
n=19\end{array}$ \\
\hline $\mathrm{ADF}$ & - & & $\begin{array}{l}355 \pm 31.0 \\
n=11\end{array}$ & $\begin{array}{l}269 \pm 53.8 \\
n=7\end{array}$ & $\begin{array}{l}305 \pm 59.0 \\
n=12\end{array}$ & - & - & $\begin{array}{l}237 \pm 37.5 \\
n=18\end{array}$ \\
\hline $\mathrm{CP}^{\mathrm{a}}$ & - & - & $\begin{array}{l}185 \pm 14.8 \\
n=13\end{array}$ & $\begin{array}{l}203 \pm 25.8 \\
n=9\end{array}$ & $\begin{array}{l}195 \pm 15.6 \\
n=14\end{array}$ & $\begin{array}{l}233 \pm 44.2 \\
n=4\end{array}$ & $\begin{array}{l}276 \pm 34.2 \\
n=6\end{array}$ & $\begin{array}{l}79 \pm 8.0 \\
n=23\end{array}$ \\
\hline
\end{tabular}

a FA, fatty acids; DM, dry matter; EE, ether extract; $C P$, crude protein.

by ether extraction alone and acid ether extraction (preceded by $\mathrm{HCl}$ hydrolysis) depended on the conservation of the forage: it was not significant for silages $(+2.6 \pm 6.2 \mathrm{~g} / \mathrm{kg}$ DM with hydrolysis, $n=14)$, but was significant for fresh forages $(+20.3 \pm 14.4 \mathrm{~g} / \mathrm{kg}$ DM with hydrolysis, $n=12)$ and hay $(+20.3 \pm 11.5 \mathrm{~g} / \mathrm{kg}$ DM with hydrolysis, $n=7)$. The mean difference between fat content measured with the Folch method and ether extraction was $+18.9 \pm 7.0 \mathrm{~g} / \mathrm{kg}$ DM $(n=5)$; the effect of conservation could not be statistically assessed ( +11 for silage, $n=1,+16.2$ for hay, $n=2$ and +25.5 for fresh, $n=2$ ).

\subsection{Effects of haymaking}

The effect of haymaking on the fat and FA content and composition was studied on all the species pooled. The results are given in Table 4 for the main FA, total FA and fat content: they are reported as adjusted models describing $Y$, the value of the hay, according to $X$, the value for the corresponding fresh forage. For most FA, there was no significant effect of the species, and when it was significant it was mostly due to one species (often in one publication) that differed from the others. When the intercept was not significantly different from zero, the models were forced through the origin (for 16:1, 18:0, fat and total FA). When the slopes were not significantly different from unity, they were set to 1 and only the mean change $(Y-X)$ was computed (e.g. for 18:3). For 18:2 there was no significant difference between fresh and hay $(Y=X)$. Haymaking induced a slight decrease in total fat and FA content, and among the FA a decrease in 18:3, mainly compensated for by an increase in 16:0. The decrease in 18:3 (overall between $-17 \%$ and $0 \%$ of the content in fresh forage) was higher when the drying conditions were bad (low-quality hays: wet weather or barn-dried after dampening).

\subsection{Effects of ensiling}

The effect of ensiling on the fat and FA content and composition was studied on all the species pooled except for corn: there was only one publication in the database reporting the composition of fresh corn and corresponding silage (Alves 
Table 3

Multi-species forages: fatty acid ( $\mathrm{g} / 100 \mathrm{~g}$ total FA ${ }^{\mathrm{a}}$ ) and chemical composition $\left(\mathrm{g} / \mathrm{kg} \mathrm{DM}^{\mathrm{a}}\right)$, according to conservation. The values are presented as means $\pm \mathrm{SD}$, number of observations. Only cells with more than 3 observations are reported.

\begin{tabular}{|c|c|c|c|c|}
\hline & \multicolumn{4}{|c|}{ Mean values by conservation method } \\
\hline & Fresh & Silage & Hay & Low-quality hay \\
\hline \multicolumn{5}{|c|}{$F A(g / 100 \mathrm{~g}$ total $F A)$} \\
\hline $12: 0$ & $\begin{array}{l}0.63 \pm 0.362 \\
n=21\end{array}$ & $\begin{array}{l}0.24 \pm 0.202 \\
n=16\end{array}$ & $\begin{array}{l}0.79 \pm 0.312 \\
n=4\end{array}$ & $\begin{array}{l}0.62 \pm 0.472 \\
n=4\end{array}$ \\
\hline 14:0 & $\begin{array}{l}1.00 \pm 0.451 \\
n=25\end{array}$ & $\begin{array}{l}0.87 \pm 0.550 \\
n=26\end{array}$ & $\begin{array}{l}1.04 \pm 0.554 \\
n=9\end{array}$ & $\begin{array}{l}1.55 \pm 0.834 \\
n=8\end{array}$ \\
\hline $16: 0$ & $\begin{array}{l}16.9 \pm 4.50 \\
n=51\end{array}$ & $\begin{array}{l}18.7 \pm 3.35 \\
n=58\end{array}$ & $\begin{array}{l}21.9 \pm 4.56 \\
n=25\end{array}$ & $\begin{array}{l}29.8 \pm 4.71 \\
n=13\end{array}$ \\
\hline $16: 1$ & $\begin{array}{l}1.00 \pm 0.924 \\
n=25\end{array}$ & $\begin{array}{l}0.83 \pm 0.649 \\
n=22\end{array}$ & $\begin{array}{l}1.69 \pm 1.512 \\
n=8\end{array}$ & $\begin{array}{l}1.80 \pm 1.470 \\
n=4\end{array}$ \\
\hline 18:0 & $\begin{array}{l}2.14 \pm 1.29 \\
n=49\end{array}$ & $\begin{array}{l}2.12 \pm 1.191 \\
n=49\end{array}$ & $\begin{array}{l}2.39 \pm 0.911 \\
n=24\end{array}$ & $\begin{array}{l}4.27 \pm 1.724 \\
n=14\end{array}$ \\
\hline $18: 1$ & $\begin{array}{l}3.84 \pm 1.758 \\
n=55\end{array}$ & $\begin{array}{l}3.40 \pm 1.229 \\
n=50\end{array}$ & $\begin{array}{l}4.18 \pm 1.430 \\
n=25\end{array}$ & $\begin{array}{l}7.23 \pm 1.012 \\
n=8\end{array}$ \\
\hline $18: 2$ & $\begin{array}{l}15.8 \pm 2.52 \\
n=53\end{array}$ & $\begin{array}{l}16.6 \pm 2.54 \\
n=59\end{array}$ & $\begin{array}{l}17.5 \pm 2.85 \\
n=25\end{array}$ & $\begin{array}{l}16.1 \pm 2.99 \\
n=12\end{array}$ \\
\hline $18: 3$ & $\begin{array}{l}52.6 \pm 9.03 \\
n=55\end{array}$ & $\begin{array}{l}49.8 \pm 7.79 \\
n=59\end{array}$ & $\begin{array}{l}47.1 \pm 7.99 \\
n=27\end{array}$ & $\begin{array}{l}23.6 \pm 6.41 \\
n=14\end{array}$ \\
\hline 20:0 & $\begin{array}{l}0.89 \pm 0.434 \\
n=18\end{array}$ & $\begin{array}{l}0.73 \pm 0.322 \\
n=21\end{array}$ & - & - \\
\hline $22: 0$ & $\begin{array}{l}0.78 \pm 0.431 \\
n=15\end{array}$ & $\begin{array}{l}1.12 \pm 0.515 \\
n=19\end{array}$ & - & - \\
\hline Chemical ( $\mathrm{g} / \mathrm{kg}$ & & & & \\
\hline Total FA & $\begin{array}{l}20.1 \pm 8.91 \\
n=28\end{array}$ & $\begin{array}{l}17.8 \pm 4.93 \\
n=42\end{array}$ & $\begin{array}{l}12.9 \pm 5.55 \\
n=18\end{array}$ & $\begin{array}{l}7.7 \pm 2.52 \\
n=12\end{array}$ \\
\hline Ether Extract & $\begin{array}{l}27.0 \pm 9.14 \\
n=9\end{array}$ & $\begin{array}{l}29.6 \pm 9.26 \\
n=28\end{array}$ & $\begin{array}{l}21.2 \pm 7.24 \\
n=13\end{array}$ & $\begin{array}{l}16.1 \pm 8.00 \\
n=4\end{array}$ \\
\hline NDF & $\begin{array}{l}497 \pm 73.5 \\
n=25\end{array}$ & $\begin{array}{l}503 \pm 70.5 \\
n=38\end{array}$ & $\begin{array}{l}551 \pm 63.7 \\
n=13\end{array}$ & $\begin{array}{l}633 \pm 36.4 \\
n=8\end{array}$ \\
\hline $\mathrm{ADF}$ & $\begin{array}{l}297 \pm 47.8 \\
n=26\end{array}$ & $\begin{array}{l}314 \pm 35.7 \\
n=27\end{array}$ & $\begin{array}{l}339 \pm 50.3 \\
n=13\end{array}$ & - \\
\hline $\mathrm{CP}^{\mathrm{a}}$ & $\begin{array}{l}171 \pm 40.1 \\
n=40\end{array}$ & $\begin{array}{l}149 \pm 36.6 \\
n=40\end{array}$ & $\begin{array}{l}136 \pm 32.1 \\
n=20\end{array}$ & $\begin{array}{l}90.4 \pm 11.45 \\
n=10\end{array}$ \\
\hline
\end{tabular}

${ }^{a}$ FA, fatty acids; DM, dry matter; CP, crude protein.

Table 4

Effect of haymaking on $\mathrm{FA}^{\mathrm{a}}$ composition ( $\mathrm{g} / 100 \mathrm{~g}$ total FA), fat and total FA content $\left(\mathrm{g} / \mathrm{kg} \mathrm{DM}^{\mathrm{a}}\right)$ of grass and legume forages.

\begin{tabular}{|c|c|c|c|}
\hline Criterion & $\begin{array}{l}\text { Value for fresh forages } \\
\text { Mean } \pm \text { SD }\end{array}$ & $\begin{array}{l}\text { Value of hay }(Y) \text { according } \\
\text { to the value of fresh }(X)\end{array}$ & Mean change ${ }^{b}$ \\
\hline $16: 00$ & $17.7 \pm 3.67$ & $\begin{array}{l}Y=0.78 X+6.84 \\
(n=22, \text { RMSE }=2.84)\end{array}$ & 2.7 \\
\hline $16: 01$ & $2.42 \pm 0.459$ & $\begin{array}{l}Y=0.76 X \\
(n=9, \text { RMSE }=0.42)\end{array}$ & -0.56 \\
\hline $18: 00$ & $1.51 \pm 0.825$ & $\begin{array}{l}Y=1.36 X \\
(n=30, \mathrm{RMSE}=0.70)\end{array}$ & 0.62 \\
\hline $18: 01$ & $2.85 \pm 1.155$ & $\begin{array}{l}Y=0.83 X+0.95 \\
(n=28, \text { RMSE }=0.84)\end{array}$ & 0.44 \\
\hline $18: 02$ & $16.8 \pm 2.39$ & $\begin{array}{l}Y=X \\
(n=31, \mathrm{RMSE}=0.59)\end{array}$ & $-0.03\left(\mathrm{NS}^{\mathrm{c}}\right)$ \\
\hline 18:03 & $55.5 \pm 7.60$ & $\begin{array}{l}\text { Sun-cured, good weather: } Y=X-4.12 \\
\text { Low-quality: } Y=X-13.20 \\
\text { Overall: } Y=X-7.13 \\
(n=23, \text { RMSE }=1.09)\end{array}$ & -7.13 \\
\hline Total FA & $14.2 \pm 4.11$ & $\begin{array}{l}Y=0.81 X \\
(n=22, \text { RMSE }=2.26)\end{array}$ & -2.40 \\
\hline Fat & $25.9 \pm 10.50$ & $\begin{array}{l}Y=0.86 X \\
(n=19, \mathrm{RMSE}=4.76)\end{array}$ & -3.30 \\
\hline
\end{tabular}

a FA, fatty acids; DM, dry matter.

${ }^{b}$ Hay minus fresh.

${ }^{c} \mathrm{NS}$, not significantly different from zero $(\mathrm{P}>0.05)$. 
Table 5

Effect of ensiling on FA composition ( $\mathrm{g} / 100 \mathrm{~g}$ total $\mathrm{FA}^{\mathrm{a}}$ ), fat and total FA content $\left(\mathrm{g} / \mathrm{kg} \mathrm{DM}^{\mathrm{a}}\right)$ of grass and legume forages.

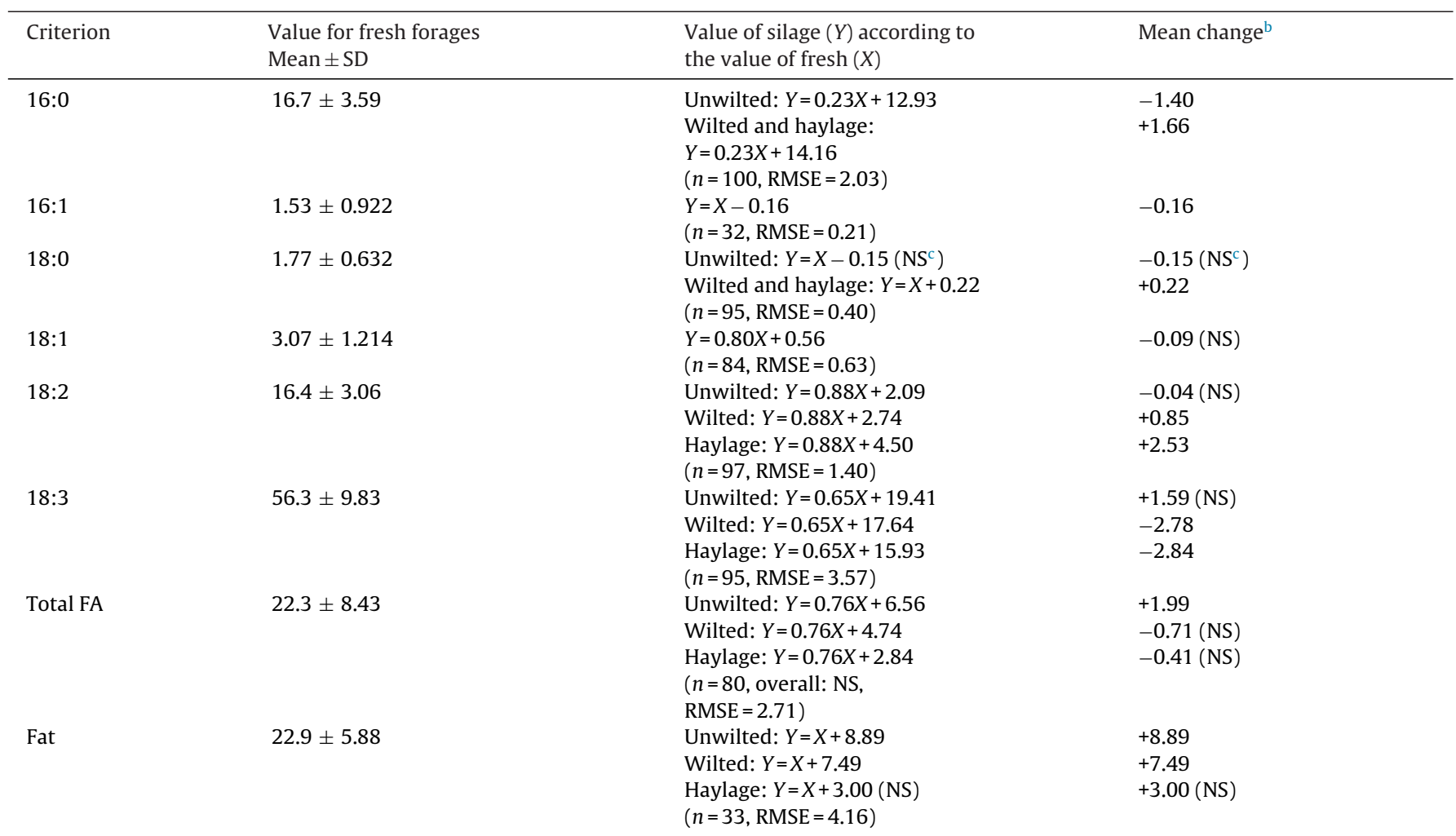

\footnotetext{
a FA, fatty acids; DM, dry matter.

b Silage minus fresh.

c NS, not significantly different from zero ( $\mathrm{P}>0.05)$.
}

et al., 2011). It reports no effect on total FA content, and a significant decrease in 17:0, 22:0, 26:0 and of all the C18 FA (all expressed in $\mathrm{g} / 100 \mathrm{~g}$ total FA), except 18:1-cis11, which increased. The other FA contents were not significantly changed by ensiling.

For the other species, the ensiling methods were split between unwilted silage (resulting in DM contents between 168 and $245 \mathrm{~g} / \mathrm{kg}$ of fresh matter), wilted silages (DM between 212 and $432 \mathrm{~g} / \mathrm{kg}$ fresh matter) and haylages (DM between 488 and $700 \mathrm{~g} / \mathrm{kg}$ fresh matter). For most FA, there was no significant effect of the species, and when it was significant it was mostly due to one species (often in one publication) that differed from the others. The type of silage had a significant effect on almost all the variables studied (Table 5). Ensiling induced a slight increase in fat content (higher for unwilted silages, and not significant for haylages), and in total FA (only significant for unwilted silages). On the FA expressed as g/100 $\mathrm{g}$ FA, the changes induced by ensiling were relatively minor, when significant (generally less than $10 \%$ of the values of fresh forages). The $18: 3$ content was unaffected by ensiling without wilting, and was lowered by $5 \%$ on average for wilted silage and haylage.

\subsection{Effects of ensiling additives}

There were 8 publications (Dewhurst and King, 1998; Warren et al., 2002; Boufaied et al., 2003; Shingfield et al., 2005; Arvidsson et al., 2008b, 2009; Van Ranst et al., 2009; Alves et al., 2011) comparing silages with and without additives and (or) different additives, corresponding to 21 forages with no additive and their counterparts with additives ( $n=68$ observations). We removed the corn silages of Alves et al. (2011), all the others being grasses or legumes. On corn, Alves et al. (2011) found no significant effect of the additives (biological inoculant or formate) on the FA content or composition. For each forage, we computed the difference between corresponding silages with and without additive. Based on a graphical study of these differences, the additives were grouped into formate vs. all the other additives, i.e. and (or) enzymes, buffer and formaldehyde. There were a total of 19 comparisons between formate addition and no additive, and 20 comparisons between other additives and no additive. The only significant differences from silages without additive were observed on total FA content (no effect of formate, decrease of $1.1 \mathrm{~g} / \mathrm{kg}$ DM by other additives), on 16:0 (decrease of $0.88 \mathrm{~g} / 100 \mathrm{~g}$ total FA by formate, no effect of the other additives) and on 18:3 (increase of $1.37 \mathrm{~g} / 100 \mathrm{~g}$ total FA by formate, no effect of the other additives). 


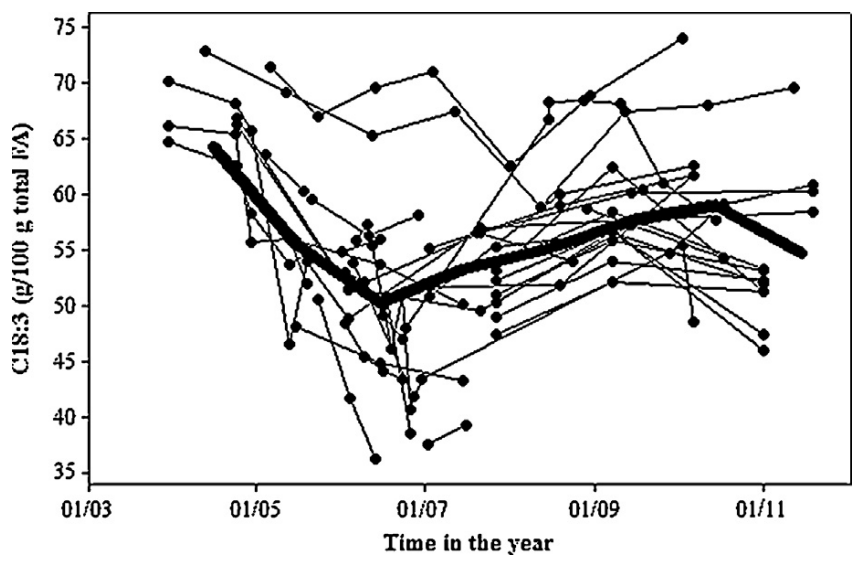

Fig. 1. Content of $18: 3$ (g/100 g fatty acids) according to the time in the year. The thin lines link the data corresponding to the same forage within the same publication, harvested at different times of the year, the thick line is the average per month (see also Table 6).

\subsection{Effects of vegetation stage and relationships with chemical composition}

Determining the effect of vegetation stage on fat, FA content and composition was rather difficult due to the variety of designs used in the publications: some authors compared harvesting dates (with or without cuttings in the meantime), others the regrowth interval (also confounded with the date or number of cuttings), others the number of cuttings (confounded with the date or regrowth interval), etc. All the publications available in the database dealing with vegetation stages studied fresh forages only. Three approaches were chosen: (i) studying the effect of the time in the year, (ii) studying the effect of the regrowth interval and (iii) a global approach to the relationships between FA composition and other chemical characteristics, across all the forages that were harvested at different vegetation stages.

For the first approach, we selected the forages that were harvested and analyzed at different times of the year. When these data were plotted against the time of the year (Fig. 1, all data were from the Northern Hemisphere in temperate climates, i.e., in Europe and North America), some well-known features appeared, such as the decrease in 18:3 from the beginning of May to the beginning of July, followed by an increase until September, corresponding to re-growth vegetation cycles. The resulting models of the FA composition and content according to the month are given in Table 6, the effect of month being highly significant $(\mathrm{P}<0.001)$ for all the criteria. The contents of $18: 3$ and total FA were minimal in June and July, corresponding to a maximum for most of the other FA.

For the second approach, a homogenous dataset was extracted from the sub-database on vegetation stages, which compared different regrowth intervals for the same forage. There were 4 publications reporting such designs (Dewhurst et al., 2001; Elgersma et al., 2003, 2005; Witkowska et al., 2008), corresponding to 7 forages (6 perennial ryegrass and 1 hybrid ryegrass), with regrowth intervals between 20 and 38 days. Total FA, CP and 18:3 decreased when regrowth interval increased, whereas the other FA increased, except for 18:1, which was not significantly affected (Table 7).

The global approach was based on the whole sub-database on vegetation stages, in which 72 forages were sampled at two or more stages (241 observations after removal of the outliers). In addition to the FA content, the most often reported chemical components were CP ( $n=24$ forages), OM (organic matter, $n=18$ ), ADF and NDF ( $n=16)$. Crude protein was chosen as a predictor, since it was the most often reported and the variable most closely related, within forage, to the fat and FA contents. The model equations of fat and FA according to CP are given in Table 8. In this dataset, the CP content ranged between 80 and $250 \mathrm{~g} / \mathrm{kg}$ of DM. These models were adjusted within-forage. The contents of 18:2 and 18:3 were quadratic functions of CP, with a decrease (for 18:2) or increase (for 18:3) between 80 and $200 \mathrm{~g} / \mathrm{kg}$ DM in CP content, and no significant modification over $200 \mathrm{~g} / \mathrm{kg}$ DM in CP content. The content of 18:0 was not significantly related to CP content.

Table 6

Effect of the time in the year (Northern Hemisphere) on FA composition (g/100 g total FA) and total FA content ( $\mathrm{g} / \mathrm{kg}$ DM ${ }^{\mathrm{a}}$ ) of pure grasses and pasture.

\begin{tabular}{|c|c|c|c|c|c|c|}
\hline Month $^{\mathrm{b}}$ & $16: 0$ & $18: 0$ & $18: 1$ & $18: 2$ & $18: 3$ & Total FA \\
\hline April & 13.86 & 1.96 & 2.31 & 12.66 & 64.33 & 23.3 \\
\hline May & 16.42 & 2.62 & 3.72 & 15.86 & 55.58 & 16.8 \\
\hline June & 18.62 & 2.87 & 4.07 & 15.89 & 50.33 & 14.2 \\
\hline July & 18.59 & 3.22 & 4.01 & 15.48 & 53.28 & 16.7 \\
\hline August & 18.00 & 2.60 & 3.18 & 14.18 & 55.11 & 16.7 \\
\hline September & 17.50 & 2.31 & 2.84 & 14.36 & 57.74 & 19.1 \\
\hline October & 16.76 & 2.64 & 2.83 & 13.62 & 59.00 & 20.2 \\
\hline RMSE & 2.05 & 0.51 & 1.17 & 1.90 & 5.21 & 4.5 \\
\hline
\end{tabular}

a FA, fatty acids; DM, dry matter.

b The values are LS means by month: the mean value for each month thus corresponds to mid-month. 
Table 7

Effect of regrowth interval on FA composition (g/100 g total FA ${ }^{\mathrm{a}}$ ), total FA and $\mathrm{CP}^{\mathrm{a}}$ contents (g/kg DM ${ }^{\mathrm{a}}$ ) of ryegrass, and adjusted corresponding to 20 and 38 days of regrowth.

\begin{tabular}{|c|c|c|c|}
\hline \multirow[t]{2}{*}{ Criterion } & \multirow[t]{2}{*}{ Models using the regrowth interval $d$ (days) } & \multicolumn{2}{|c|}{ Adjusted values $^{\mathrm{b}}$} \\
\hline & & $d=20$ & $d=38$ \\
\hline $16: 0$ & $=10.12+0.16 d(n=16$, RMSE $=0.48)$ & 13.32 & 16.20 \\
\hline $18: 0$ & $=0.81+0.026 d(n=6$, RMSE $=0.09)$ & 1.33 & 1.80 \\
\hline $18: 1$ & $=1.23+0.029 d\left(\mathrm{NS}^{\mathrm{c}}\right)(n=11, \mathrm{RMSE}=0.35)$ & 1.80 & 2.32 \\
\hline $18: 2$ & $=9.02+0.12 d(n=16$, RMSE $=0.99)$ & 11.42 & 13.58 \\
\hline $18: 3$ & $=79.51-0.37 d(n=16, \mathrm{RMSE}=1.25)$ & 72.11 & 65.45 \\
\hline Total FA & $=32.1-0.42 d(n=16$, RMSE $=1.51)$ & 23.7 & 16.1 \\
\hline $\mathrm{CP}$ & $=253-3.7 d(n=10, \mathrm{RMSE}=4.58)$ & 179 & 112 \\
\hline
\end{tabular}

a FA, fatty acids; CP, crude protein; DM, dry matter.

b Estimated using the equations with $d=20$ and $d=38$.

c NS, not significant $(\mathrm{P}>0.05)$.

Table 8

Effect of vegetation stage on FA F $^{\mathrm{a}}$ composition ( $\mathrm{g} / 100 \mathrm{~g}$ total FA), fat and total FA content ( $\mathrm{g} / \mathrm{kg} \mathrm{DM}^{\mathrm{a}}$ ) of grasses and pastures: models using crude protein $\left(\mathrm{CP}^{\mathrm{a}}\right)$ content.

\begin{tabular}{ll}
\hline Criterion & Models using CP $(\mathrm{g} / 100 \mathrm{~g} \mathrm{DM})$ \\
\hline $16: 0$ & $=18.40-0.23 \mathrm{CP}(n=82, \mathrm{RMSE}=1.23)$ \\
$18: 0$ & $=1.58-0.010 \mathrm{CP}\left(\mathrm{NS}^{\mathrm{b}}\right)(n=57, \mathrm{RMSE}=0.34)$ \\
$18: 1$ & $=4.20-0.11 \mathrm{CP}(n=62, \mathrm{RMSE}=0.49)$ \\
$18: 2$ & $=26.52-1.13 \mathrm{CP}+0.026 \mathrm{CP}^{2}(n=82, \mathrm{RMSE}=1.28)$ \\
$18: 3$ & $=41.46+2.23 \mathrm{CP}-0.050 \mathrm{CP}^{2}(n=82, \mathrm{RMSE}=3.26)$ \\
Total FA & $=4.5+0.089 \mathrm{CP}(n=61, \mathrm{RMSE}=2.93)$ \\
Fat & $=4.9+0.15 \mathrm{CP}(n=22, \mathrm{RMSE}=4.09)$ \\
\hline
\end{tabular}

a FA, fatty acids; DM, dry matter; $\mathrm{CP}$, crude protein.

b NS, not significant $(\mathrm{P}>0.05)$.

Table 9

Effect of $\mathrm{N}$ application for the cut ( $\mathrm{kg} \mathrm{N} / \mathrm{ha}$ ) on $\mathrm{FA}^{\mathrm{a}}$ composition (g/100 g total FA), total FA and CPa contents (g/kg DM ${ }^{\mathrm{a}}$ ) of grass forages.

\begin{tabular}{ll}
\hline Criterion & Models using $\mathrm{N}$ fertilization $(\mathrm{kg} \mathrm{N} / \mathrm{ha})$ \\
\hline $16: 0$ & $=16.07-0.012 \mathrm{~N}(n=22, \mathrm{RMSE}=0.41)$ \\
$18: 0$ & $=2.20-0.0029 \mathrm{~N}(n=10, \mathrm{RMSE}=0.14)$ \\
$18: 1$ & $=4.69-0.0077 \mathrm{~N}(n=16, \mathrm{RMSE}=0.32)$ \\
$18: 2$ & $=17.36-0.014 \mathrm{~N}(n=34, \mathrm{RMSE}=0.65)$ \\
$18: 3$ & $=58.53+0.033 \mathrm{~N}(n=34, \mathrm{RMSE}=1.54)$ \\
Total FA & $=16.5+0.039 \mathrm{~N}(n=34, \mathrm{RMSE}=1.49)$ \\
CP & $=101+0.77 \mathrm{~N}(n=14, \mathrm{RMSE}=16.7)$ \\
\hline
\end{tabular}

a FA, fatty acids; CP, crude protein; DM, dry matter.

\subsection{Effects of $N$ fertilization}

Five publications (Boufaied et al., 2003; Elgersma et al., 2005; Doreau et al., 2007; Arvidsson et al., 2008a; Witkowska et al., 2008) compared various levels of $\mathrm{N}$ fertilization on the same forage, representing 15 forages with two or more fertilization levels (a total of 34 observations). The independent variable reported in all publications was $\mathrm{N}$ application for the cut in $\mathrm{kg} / \mathrm{ha}$, which ranged between zero (not fertilized) and 120. Across this range of fertilization levels, the response of FA content and composition was linear, $\mathrm{N}$ fertilization increasing total FA and CP contents and the content of 18:3, whereas the content of all the other FA decreased (Table 9).

\section{Discussion}

\subsection{Methodological issues}

The main difficulty we faced in determining mean values for the main forage categories was the broad dispersion of the data. Although the total number of data items was high enough for a quantitative analysis, once they were split among species, conservations, analytical methods, etc., homogenous datasets included only very few data, often from a very small number of publications, with a low representativeness. In addition, the forages were often incompletely described, with partial or no description of the vegetation stage, cultivation conditions, etc. For these reasons, we opted to pool the data and report global estimates, perhaps less accurate, but more robust. The analytical methods introduced a bias, especially the different methods used for fat determination (Palmquist and Jenkins, 2003). Fat content as estimated by the Folch method is much higher than when estimated by ether extraction. In addition, when fat is determined by ether extraction, the nature of 
Table 10

Comparison of the magnitude of effects of various factors on the total FA ${ }^{\mathrm{a}}$ content $\left(\mathrm{g} / \mathrm{kg} \mathrm{DM}^{\mathrm{a}}\right)$ and 18:3 content ( $\mathrm{g} / 100 \mathrm{~g}$ total FA) (estimated from the results of the present study).

\begin{tabular}{|c|c|c|c|}
\hline Factor & Effect of & Total FA (g/kg DM) & $18: 3(\mathrm{~g} / 100 \mathrm{~g}$ total FA $)$ \\
\hline \multirow{5}{*}{ Conservation ( $v s$. fresh forage) } & Haymaking & -2.4 & $\begin{array}{l}\text { Average: }-7.13 \\
\text { Good quality: }-4.12 \\
\text { Bad quality: }-13.20\end{array}$ \\
\hline & Unwilted silage & +2.0 & $\mathrm{NS}^{\mathrm{b}}$ \\
\hline & Wilted silage & NS & -2.78 \\
\hline & Haylage & NS & -2.84 \\
\hline & Formate in silage & NS & +1.37 \\
\hline \multirow{3}{*}{ Vegetation stage } & Cutting date $(\min -\max )$ & -9.1 & -14.00 \\
\hline & Decrease in $\mathrm{CP}^{\mathrm{a}}$ by $50 \mathrm{~g} / \mathrm{kg}$ & -4.5 & -1.20 to $-4.90^{c}$ \\
\hline & Regrowth interval: +10 days & -4.2 & -3.60 \\
\hline Fertilization & $+50 \mathrm{~kg} \mathrm{~N} / \mathrm{ha}$ & +1.9 & +1.65 \\
\hline
\end{tabular}

a FA, fatty acids; DM, dry matter; $\mathrm{CP}$, crude protein.

b NS, not significant $(\mathrm{P}>0.05)$.

c Quadratic model.

the ether is not always mentioned in the publications, although extraction by diethyl ether, which was mainly used before the 1980s, yields slightly higher values than extraction by petroleum ether (Palmquist and Jenkins, 2003). We were able to estimate the differences between ether extraction (the most frequent method used in the publications from the database) and the two other main methods (ether extract preceded by hydrolysis, and the Folch method). These differences were higher for fresh forages and hays than for silages (Elgersma et al., 2003). The estimation of the total FA content from the fat content also depended on the method used for fat determination. For corn silage, after exclusion of some extreme data, we found a negative relationship between fat and total FA contents, unlike Khan et al. (2012). However, across all the forages, no significant effect of the method used for total FA determination was found on the various relationships reported in the present study.

\subsection{Factors modifying FA content and composition of forages}

The main factors influencing the fat and FA content and composition of forages are already known (see reviews of Dewhurst et al., 2006; Khan et al., 2012): species (and to a lesser degree cultivar), vegetation stage, conditions of conservation and $\mathrm{N}$ fertilization. From the quantitative results of the present study, we compared the magnitude of their effects on total FA and on 18:3, which is the main FA in forages, and the most useful for enhancing milk and meat quality (Table 10). The predominant factor was the vegetation stage, with large variations in total FA and especially 18:3 contents over the year, consistent with the conclusions of Khan et al. (2012). When the vegetation stage progressed and the forage grew older, CP decreased, along with fat, total FA and the content of 18:3, while NDF increased, along with the content of 16:0, 18:0, 18:1 and 18:2 in total FA (Table 7). These variations are first due to the decrease in the proportions of leaves (Dewhurst et al., 2001), which are richer than stems and seeds in membrane lipids, and thus in 18:3 (Buccioni et al., 2012), and then to the maturation and senescence of leaves and an increase in the fiber and storage fractions (grain). The second factor was haymaking, and especially bad drying conditions, which can dramatically decrease the 18:3 content (Table 4). This could result from various processes occurring during the drying time: lipolysis and oxidation of the polyunsaturated FA (Molloy et al., 1975; Dewhurst et al., 2006), loss of leaves during forage handling, or extended respiration within the plant cells until DM content reached $850 \mathrm{~g} / \mathrm{kg}$ fresh matter (Baumont et al., 2011). With good drying conditions (swift drying process) the loss of $18: 3$ was lower ( -2.8 to $4 \mathrm{~g} / 100 \mathrm{~g}$ total FA), as exemplified with good-quality hays, wilted silage and haylage (Table 5). The loss of total FA was minor in these cases. For unwilted silages, the content of 18:3 was unaffected by the ensiling process, and the FA content was even improved, probably due to the loss of soluble contents of the forages, which in turn increase the FA content in total DM (Baumont et al., 2011). However, although their FA profile is not altered, forage lipids undergo extensive lipolysis during ensiling, leading to a high content of free FA in silages (Elgersma et al., 2003; Van Ranst et al., 2009). Addition of formate to the silage had a slight protective effect on 18:3, which may be the result of a better silage quality, even though no detailed mechanism for this protection could be found in the literature (Van Ranst et al., 2009). Compared with the effects of vegetation stage and conservation method, the effects of $\mathrm{N}$ fertilization were minor, with a slight increase in total FA and the content of 18:3 and a decrease in the contents of the other FA (Table 9). These changes are consistent with the increase in $\mathrm{CP}$ in forages when $\mathrm{N}$ fertilization increases. This could be due to an improved proportion of vegetative organs in the plant, richer in membrane lipids and polyunsatured FA (Boufaied et al., 2003).

The effect of species was more difficult to assess: the mean values display no major differences between species or even botanical families (Tables 1-3). However, within publications, some significant differences in FA content and composition were sometimes found between species (e.g. Boufaied et al., 2003) or cultivars (Boufaied et al., 2003; Palladino et al., 2009). It is possible that some of the differences observed between species or cultivars in individual publications result from differences in vegetation stage at harvest (Boufaied et al., 2003), which vanish when averaged over several publications. 
There was also a limited set of publications comparing pastures differing in their species composition (generally proportion of legumes or other dicotyledonous plants). In these publications (Fievez et al., 2002; Morel et al., 2006a,b; Steinshamn et al., 2006; Lourenço et al., 2007; Steinshamn and Thuen, 2008), the content of 18:3 increased when the proportion of grasses increased (on average $18: 3$ increased by $0.9 \mathrm{~g} / 100 \mathrm{~g}$ FA for each $10 \%$ increase in grass proportion), and reciprocally the content of 18:3 decreased when the proportion of legumes increased, consistent with the conclusions of Farruggia et al. (2008). The proportion of the other dicotyledonous plants had no significant effect. The total FA content was not significantly altered by the botanical composition. Overall, the differences between species and cultivars seemed to be lower than those resulting from vegetation stages or conservation.

\subsection{Relationship between FA and other constituents}

The mean values of the forage categories (species $\times$ conservation) were sometimes calculated from a small number of data, or, conversely, did not reflect the variability of the individual values. In order to refine these mean values, estimates can be obtained by equations using the $\mathrm{CP}$ content of the forage, for example to take into account the effect of vegetation stage. The close relationship between CP content and FA composition has already been observed (Palladino et al., 2009; Khan et al., 2012). This is partially explained by the same location of CP and FA in the plant in leaves (photosynthetic organs) rather than in stems. A similar approach, to estimate the FA composition of the forage from its chemical composition, has been recently proposed, focused on grass and corn silages, by Khan et al. (2012). The equations proposed by Khan et al. (2012) to estimate the FA contents (in $\mathrm{g} / \mathrm{kg} \mathrm{DM}$ ) involve predominantly lignin and fat for grass silage, and fat, DM, and organic matter digestibility for corn silage. In the present study, we used mainly CP for all forages except for corn silage, because it was the most often reported component in the publications used, and because CP content of forages is routinely determined in the field. For corn silage, we found that 18:2 was most closely related to the DM content of the silage and 18:3 by its NDF content, consistent with the correlations found by Khan et al. (2012) on their corn silage samples. In the present study, the relationships between FA composition and CP content were very similar (except for the intercepts of the equations) when they were adjusted from data involving ryegrass harvested at different regrowth intervals (Table 7), from single-species and multi-species forages harvested at different stages (Table 8), or in response to increasing $\mathrm{N}$ fertilization (Table 9). In all these datasets, an increase in CP is associated with an increase in total FA (around $0.8 \mathrm{~g} / \mathrm{kg}$ for each $10 \mathrm{~g} / \mathrm{kg}$ DM increase in CP), in the content of 18:3 (around 0.5/100 g total FA for each $10 \mathrm{~g} / \mathrm{kg}$ DM increase in CP) and a decrease in the contents of 16:0, 18:0,18:1 and 18:2. This is probably linked to the same determinants for the CP content and the FA composition, both linked to the proportion and age of the vegetative organs of the plant. Thus, young forages of high nutritional value are also those that have a high FA content and FA composition conducive to high nutritional quality of animal products.

\section{Conclusions}

Despite the heterogeneity of the available data, the role of several factors on FA content and composition of forages has been assessed, and an attempt to compare their magnitude has been made. The relationships reported in this study highlight the importance of good harvest and drying conditions, especially for haymaking, to preserve the FA composition of the forage. The relationships between vegetation stage and FA content and composition show a trade-off between forage yield (increasing with the vegetation stage) and polyunsaturated FA content (decreasing with vegetation stage). The mean values (possibly refined using measurements of the $\mathrm{CP}$ content of the forage) could be useful to estimate the amount of FA ingested by the animals, and thus the possible outcomes in terms of FA composition of the products.

\section{Appendix 1. List of the publications included in the focused database}

Alves, S.P., Cabrita, A.R.J., Jeronimo, E., Bessa, R.J.B., Fonseca, A.J.M., 2011. J. Anim. Sci. 89, 2537-2545.

Arrigo, Y., 2010. Rech. Agron. Suisse 1, 366-371.

Arvidsson, K., Gustafsson, T., Martinsson, K., 2008a. XXI International Grassland Congress, VIII International Rangeland Congress, China, p. 671.

Arvidsson, K., Gustavsson, A.-M., Martinsson, K., 2008b. In: Hopkins, A., Gustafsson, T., Bertilsson, J., Dalin, G., NilsdotterLinde, N., Spörndly, E. (Eds.), 22nd General Meeting of the European Grassland Federation, European Grassland Federation, Uppsala, Sweden, pp. 654-656.

Arvidsson, K., Gustavsson, A.-M., Martinsson, K., 2009a. Anim. Feed Sci. Technol. 148, 241-252.

Arvidsson, K., Gustavsson, A.-M., Martinsson, K., 2009b. Anim. Feed Sci. Technol. 151, 143-152.

Bauchart, D., Verite, R., Remond, B., 1984. Can. J. Anim. Sci. 64, 330-331.

Boufaied, H., Chouinard, P.Y., Tremblay, G.F., Petit, H.V., Michaud, R., Belanger, G., 2003. Can. J. Anim. Sci. 83, 501-511.

Chow, T.T., Fievez, V., Elgersma, A., De Smets, D., 2004. Grassland Sci. Eur. 9, 981-983.

Clapham, W.M., Foster, G.F., Neel, J.P.S., Fedders, J.M., 2005. J. Agric. Food Chem. 53, 10068-10073.

Cone, J.W., Meulenberg, S., Elgersma, A., Hendriks, W.H., 2008. In: Hopkins, A., Gustafsson, T., Bertilsson, J., Dalin, G., Nilsdotter-Linde, N., Spörndly, E. (Eds.), 22nd General Meeting of the European Grassland Federation, European Grassland Federation, Uppsala, Sweden, pp. 450-452. 
Dewhurst, R.J., King, P.J., 1998. Grass For. Sci. 53, 219-224.

Dewhurst, R.J., Moorby, J.M., Scollan, N.D., Tweed, J.K.S., Humphreys, M.O., 2002. Grass For. Sci. 57, 360-366.

Dewhurst, R.J., Scollan, N.D., Youell, S.J., Tweed, J.K.S., Humphreys, M.O., 2001. Grass For. Sci. 56, 68-74.

Dhiman, T.R., Helmink, E.D., McMahon, D.J., Fife, R.L., Pariza, M.W., 1999. J. Dairy Sci. 82, 412-419.

Doreau, M., Rearte, D., Portelli, J., Peyraud, J.L., 2007. Eur. J. Lipid Sci. Technol. 109, 790-798.

Doreau, M., Ueda, K., Poncet, C., 2003. Trop. Subtrop. Agroecosyst. 3, 289-293.

Elgersma, A., Ellen, G., Horst, H., Muuse, B.G., Boer, H., Tamminga, S., 2003a. (Lolium perenne L.). Grass For. Sci. 58, $323-331$. Elgersma, A., Ellen, G., Horst, H.v.d., Muuse, B.G., Boer, H., Tamminga, S., 2003b. Anim. Feed Sci. Technol. 108, $191-205$.

Elgersma, A., Maudet, P., Witkowska, I.M., Wever, A.C., 2005. Ann. Appl. Biol. 147, 145-152.

Elgersma, A., Van der Hoeven, E., Witkowska, I., Smit, H.J., 2008. In: Hopkins, A., Gustafsson, T., Bertilsson, J., Dalin, G., Nilsdotter-Linde, N., Spörndly, E. (Eds.), 22nd General Meeting of the European Grassland Federation, European Grassland Federation, Uppsala, Sweden, pp. 388-390.

Ferlay, A., Martin, B., Pradel, P., Coulon, J.B., Chilliard, Y., 2006. J. Dairy Sci. 89, 4026-4041.

Gilliland, T.J., Barrett, P.D., Mann, R.L., Agnew, R.E., Fearon, A.M., 2002. J. Agric. Sci. 139, 257-273.

Hudson, B.J.F., Karis, I.G., 1974. J. Sci. Food Agric. 25, 1491-1502.

Khan, N.A., Cone, J.W., Hendriks, W.H., 2009. Anim. Feed Sci. Technol. 154, 183-192.

Leiber, F., Kreuzer, M., Nigg, D., Wettstein, H.-R., Scheeder, M.R.L., 2005. Lipids 40, 191-202.

Loor, J.J., Herbein, J.H., Polan, C.E., 2002. J. Dairy Sci. 85, 1197-1207.

Lourenço, M., Van Ranst, G., De Smet, S., Raes, K., Fievez, V., 2007. Animal 1, 537-545.

Mayland, H.F., Molloy, L.F., Collie, T.W., 1976. Agron. J. 68, 979-984.

Mir, P.S., Bittman, S., Hunt, D., Entz, T., Yip, B., 2006. Can. J. Anim. Sci. 86, 279-290.

Morel, I., Wyss, U., Collomb, M., 2006a. Rev. Suisse Agric. 38, 115-120.

Morel, I., Wyss, U., Collomb, M., Butikofer, U., 2006b. Rev. Suisse Agric. 38, 9-15.

Noci, F., Monahan, F.J., Scollan, N.D., Moloney, A.P., 2007. Br. J. Nutr. 97, 502-513.

Outen, G.E., Beever, D.E., Osbourn, D.F., 1974. J. Sci. Food Agric. 25, 981-987.

Outen, G.E., Beever, D.E., Osbourn, D.F., Thomson, D.J., 1975. J. Sci. Food Agric. 26, 1381-1389.

Palladino, R.A., O’Donovan, M., Kennedy, E., Murphy, J.J., Boland, T.M., Kenny, D.A., 2009. Grass For. Sci. 64, $219-226$.

Pavan, E., Duckett, S.K., Andrae, J.G., 2007. J. Anim. Sci. 85, 1330-1339.

Peiretti, P.G., Meineri, G., 2008. J. Sci. Food Agric. 88, 1850-1854.

Renna, M., Collomb, M., Munger, A., Wyss, U., 2010. J. Sci. Food Agric. 90, 1256-1267.

Saito, T., Onuma, T., Akimoto, B., Nakanishi, T., 1970. Jap. J. Dairy Sci. 21, A70-A82.

Salawu, M.B., Adesogan, A.T., Dewhurst, R.J., 2002. J. Dairy Sci. 85, 3035-3044.

Scollan, N.D., Lee, M.R.F., Enser, M., 2003. Anim. Res. 52, 501-511.

Shingfield, K.J., Salo-Väänänen, P., Pahkala, E., Toivonen, V., Jaakkola, S., Piironen, V., Huhtanen, P., 2005. J. Dairy Res. 72, 349-361.

Tornambe, G., Martin, B., Pradel, P., Grigoli, A.d., Bonanno, A., Chilliard, Y., Ferlay, A., di Grigoli, A., 2010. In: Schnyder, H., Isselstein, J., Taube, F., Auerswald, K., Schellberg, J., Wachendorf, M., Herrmann, A., Gierus, M., Wrage, N., Hopkins, A. (Eds.), Grassland in a changing world. Proceedings of the 23rd General Meeting of the European Grassland Federation, Kiel, Germany, 29th August-2nd September 2010, Mecke Druck und Verlag, Duderstadt, Germany, pp. 628-630.

Ueda, K., Chabrot, J., Doreau, M., 2002. Multi-function grasslands: quality forages, animal products and landscapes. Proceedings of the 19th General Meeting of the European Grassland Federation, La Rochelle, France, 27-30 May 2002, 98-99.

van Dorland, H.A., Kreuzer, M., Leuenberger, H., Wettstein, H.R., 2008. J. Sci. Food Agric. 88, 77-85.

Van Ranst, G., Fievez, V., De Riek, J., Van Bockstaele, E., 2008. In: Hopkins, A., Gustafsson, T., Bertilsson, J., Dalin, G., NilsdotterLinde, N., Spörndly, E. (Eds.), 22nd General Meeting of the European Grassland Federation, European Grassland Federation, Uppsala, Sweden, pp. 684-686.

Van Ranst, G., Fievez, V., De Riek, J., Van Bockstaele, E., 2009. Anim. Feed Sci. Technol. 150, 62-74.

Van Ranst, G., Fievez, V., Vandewalle, M., Riek, J.D., Bockstaele, E.V., 2009. Grass For. Sci. 64, 196-207.

Van Ranst, G., Fievez, V., Vandewalle, M., Van Waes, C., De Riek, J., Van Bockstaele, E., 2010. Animal 4, 1528-1540.

Vanhatalo, A., Kuoppala, K., Toivonen, V., Shingfield, K.J., 2007. Eur. J. Lipid Sci. Technol. 109, 856-867.

Walker, G.P., Doyle, P.T., Heard, J.W., Francis, S.A., 2004. Anim. Prod. Aust. 25, 192-195.

Warren, H.E., Tweed, J.K.S., Youell, S.J., Dewhurst, R.J., Lee, M.R.F., Scollan, N.D., 2002. Multi-function grasslands: quality forages, animal products and landscapes. In: Proceedings of the 19th General Meeting of the European Grassland Federation, La Rochelle, France, 27-30 May 2002, 100-101.

Whiting, C.M., Mutsvangwa, T., Walton, J.P., Cant, J.P., McBride, B.W., 2004. Anim. Feed Sci. Technol. 113, $27-37$.

Witkowska, I., Wever, C., Gort, G., Elgersma, A., 2008. Agron. J. 100, 1371-1379.

Wyss, U., Collomb, M., 2008. Rev. Suisse Agric. 40, 46-50.

Wyss, U., Morel, I., Collomb, M., 2006. In: Lloveras, J., Gonzalez-Rodriguez, A., Vazquez-Yanez, O., Pineiro, J., Santamaria, O., Olea, L., Poblaciones, M.J.(Eds.), 21st General Meeting of the European Grassland Federation, European Grassland Federation, Badajoz, Spain, pp. 348-350. 
Yang, U.M., Fujita, H., 1997. Grassland Sci. 42, 289-293.

\section{Appendix 2. List of the publications included in the non-focused database}

AbuGhazaleh, A.A., Schingoethe D.J., Hippen A.R., 2001. J. Dairy Sci. 84, 1845-1850.

AbuGhazaleh, A.A., Schingoethe, D.J., Hippen, A.R., Kalscheur, K.F., Whitlock, L.A., 2002. J. Dairy Sci. 85, 2266-2276

AbuGhazaleh, A.A., Schingoethe, D.J., Hippen, A.R., Whitlock, L.A., 2002. J. Dairy Sci. 85, 624-631.

Agenäs, S., Holtenius, K., Griinari, M., Burstedt, E., 2002. Acta Agric. Scand. Sect. A, Anim. Sci. 52, 25-33.

Al-Mabruk, R.M., Beck, N.F.G., Dewhurst, R.J., 2004. J. Dairy Sci. 87, 406-412.

Alves, S.P., Cabrita, A.R.J., Fonseca, A.J.M., Bessa, R.J.B., 2009. J. Agric. Food Chem. 57, 10793-10797.

Atkinson, R.A., Scholljegerdes, E.J., Lake, S.L., Nayigiguhu, V., Hess, B.W., Rule, D.C., 2006. J. Anim. Sci. 84, 387-396.

Aurousseau, B., Bauchart, D., Calichon, E., Micol, D., Priolo, A., 2004. Meat Sci. 66, 531-541.

Bargo, F., Muller, L.D., Delahoy, J.E., Cassidy, T.W., 2002. J. Dairy Sci. 85, 1777-1792.

Bartsch, B.D., Ellis, N.J.S., McLean, D.M., Radcliffe, J.C., 1976. Austr. J. Agric. Res. 27, 917-927.

Bauchart, D., Doreau, M., Kindler, A., 1987. J. Dairy Sci. 70, 71-80.

Bauchart, D., Poncet, C., 1984. INRA, France, unpublished data.

Beever, D.E., 2005. Anim. Sci. 80, 225-238.

Bines, J.A., Brumby, P.E., Storry, J.E., Fulford, R.J., Braithwaite, G.D., 1978. J. Agric. Sci. 91, 135-150.

Body, D.R., Hansen, R.P., 1978. J. Sci. Food. Agric. 29, 107-114.

Boken, S.L., Staples, C.R., Sollenberger, L.E., Jenkins, T.C., Thatcher, W.W., 2005. J. Dairy Sci. 88, 4258-4272.

Boufaïed, H., Chouinard, P.Y., Tremblay, G.F., Petit, H.V., Michaud, R., Bélanger, G., 2003. Can. J. Anim. Sci. 83, 501-511.

Cant, J.P., Fredeen, A.H., MacIntyre, T., Gunn, J., Crowe, N., 1997. Can. J. Anim. Sci. 77, 125-131.

Casper, D.P., Schingoethe, D.J., Eisenbeisz, W.A., 1990. J. Dairy Sci. 73, 1039-1050.

Casper, D.P., Schingoethe, D.J., Middaugh, R.P., Baer, R.J., 1988. J. Dairy Sci. 71, 1267-1274.

Chichlowski, M.W., Schroeden, J.W., Park, C.S., Keller, W.L., Schimek, D.E., 2005. J. Dairy Sci. 88, 3084-3094.

Christensen, R.A., Clark, J.H., Drackley, J.K., Blum, S.A., 1998. J. Dairy Sci. 81, 1078-1088.

Christensen, R.A., Drackley, J.K., LaCount, D.W., Clark, J.H., 1994. J. Dairy Sci. 77, 1052-1069.

Clapperton, J.L., 1982. J. Sci. Food Agric. 33, 741-753.

Clapperton, J.L., Banks, W., 1985. J. Sci. Food Agric. 36, 1205-1211.

Clapperton, J.L., Banks, W., Rook, J.A.F., 1980. Proc. Nutr. Soc. 39, 64A.

Clapperton, J.L., Kelly, M.E., Banks, J.M., Rook, J.A.F., 1980. J. Sci. Food Agric. 31, 1295-1302.

Clapperton, J.L., Steele, W., 1985. J. Dairy Sci. 68, 2908-2913.

Dayani, O., Ghorbani, G., Entz, T., Ross, C.M., Shah, M.A., Beauchemin, K.A., Mir, P.S., Mir, Z., 2004. Can. J. Anim. Sci. 84, 113-124.

Delagarde, R., Peyraud, J.L., 2002. Grass Sci. Eur. 7, 554.

Dewhurst, R.J., Fisher, W.J., Tweed, J.K.S., Wilkins, R.J., 2003. J. Dairy Sci. 86, 2598-2611.

Dewhurst, R.J., Moorby, J.M., Vlaeminck, B., Fievez V., 2007. J. Dairy Sci. 90, 1775-1780.

Dhiman, T.R., Anand, G.R., Satter, L.D., Pariza, M.W., 1999. J. Dairy Sci. 82, 2146-2156.

Dhiman, T.R., Helmink, E.D., McMahon, D.J., Fife, R.L., Pariza, M.W., 1999. J. Dairy Sci. 82, 412-419.

Donovan, D.C., Schingoethe, D.J., Baer, R.J., Ryali, J., Hippen, A.R., Franklin, S.T., 2000. J. Dairy Sci. 82, 2620-2628.

Doreau, M., Chilliard, Y., 1999. Renc. Rech. Rumin. 6, 314.

Drackley, J.K., Clark, A.K., Sahlu, T., 1985. J. Dairy Sci. 68, 356-367.

Duckett, S.K., Gillis, M.H., 2010. J. Anim. Sci. 88, 2684-2691.

Elgersma, A., Ellen, G., van der Horst, H., Boer, H., Dekker, P.R., Tamminga, S., 2004. Anim. Feed Sci. Technol. 117, 13-27.

Emanuelson, M., Murphy, M., Lindberg, J.E., 1991. Anim. Feed Sci. Technol. 34, 291-309.

Enjalbert, F., Bayourthe, C., Griess, D., Moncoulon, R., 1996. Rev. Med. Vet. 147, 577-582.

Ferlay, A., Chilliard, Y., Doreau, M., 1992. J. Sci. Food Agric. 60, 31-37.

Fievez, V., 2002. Univ. Gent, Belgium, unpublished data.

Fievez, V., Ensberg, M. Chow, T. T., Demeyer, D., 2004. Commun. Agric. Appl. Biol. Sci. 69, 93-102.

Fievez, V., Vlaeminck, B., Raes, K., Chow, T.T., de Smet, S., Demeyer, D., Bruinenberg, M.H., 2002. Grass. Sci. Eur. 7, 558-559.

Finn, A.M., Clark, A.K., Drackley, J.K., Schingoethe, D.J., Sahlu, T., 1985. J. Dairy Sci. 68, 903-913.

Flachowsky, G., Erdmann, K., Hüther, L., Jahreis, G., Möckel, P., Lebzien, P., 2006. Arch. Anim. Nutr. 60, 501-511.

Flowers, G., Ibrahim, S.A., AbuGhazaleh, A.A., 2008. J. Dairy Sci. 91, 722-730.

Fredricksson Eriksson, S., Pickova, J., 2007. Meat Sci. 76, 746-754.

French, P., O’Riordan, E.G., Monahan, F.J., Caffrey, P.J., Moloney, A.P., 2003. Livest. Prod. Sci. 81, 307-317.

French, P., Stanton, C., Lawless, F., O'Riordan, E.G., Monahan, F.J., Caffrey, P.J., Moloney, A.P., 2000. J. Anim. Sci. 78, 2849-2855.

Goering, H.K., Gordon, C.H., Wrenn, T.W., Bitman, J., King, R.L., Douglas Jr, F.W., 1976. J. Dairy Sci. 59, 416-425.

Goering, H.K., Wrenn, T.R., Edmondson, L.F., Weyant, J.R., Wood, D.L., Bitman, J., 1977. J. Dairy Sci. 60, 739-747.

Grummer, R.R., 1988. J. Dairy Sci. 71, 117-123.

Hoffman, P.C., Grummer, R.R., Shaver, R.D., Broderick, G.A., Drendel, T.R., 1991. J. Dairy Sci. 74, 3468-3474. 
Hogan, J.P., Hogan, R.M., 1976. Aust. J. Agric. Res. 27, 129-138.

Hurtaud, C., Faucon, F., Couvreur, S., Peyraud, J.L., 2010. J. Dairy Sci. 93, 1429-1443.

Hussein, H.S., Merchen, N.R., Fahey, G.C., 1996. J. Dairy Sci. 79, 87-97.

Jerred, M.J., Carroll, D.J., Combs, D.K., Grummer, R.R., 1990. J. Dairy Sci. 73, 2842-2854.

Jiang, J., Bjoerck, L., Fondén, R., Emanuelson, M., 1996. J. Dairy Sci. 79, 438-445.

Jones, R.A., Mustafa, A.F., Christensen, D.A., McKinnon, J.J., 2001. Anim. Feed Sci. Technol. 89, 97-111.

Kalscheur K.F., Teter, B.B., Piperova, L.S., Erdman, R.A., 1997. J. Dairy Sci. 80, 2115-2126.

Kalscheur, K.F., Teter, B.B., Piperova, L.S., Erdman, R.A., 1997. J. Dairy Sci. 80, 2104-2114.

Kay, J.K., Mackle, T.R., Auldist, M.J., Thomson, N.A., Bauman, D.E., 2004. J. Dairy Sci. 87, 369-378.

Khanal, R.C., Dhiman, T.R., 2007. Asian-Aust. J. Anim. Sci. 20, 1525-1538.

Khanal, R.C., Dhiman, T.R., Boman, R.L., McMahon, D.J., 2007. Asian-Aust. J. Anim. Sci. 20, 1374-1388.

Kim, Y.K., Schingoethe, D.J., Casper, D.P., Ludens, F.C., 1993. J. Dairy Sci. 76, 197-204.

King, K.R., Stockdale, C.R., Trigg, T.E., 1990. Aust. J. Exp. Agric. 30, 11-16.

Kitessa, S.M., Gulati, S.G., Simos, G.C., Ashes, J.R., Scott, T.W., Fleck, E., Wynn, P.C., 2004. Br. J. Nutr. 91, $271-277$.

Klusmeyer, T.H., Clark, J.H., 1991. J. Dairy Sci. 74, 3055-3067.

Kronfeld, D.S., Donoghue, S., Naylor, J.M., Johnson, K., Bradley, C.A., 1980. J. Dairy Sci. 63, 545-552.

Lee, M.R.F., Connelly, P.L., Tweed, J.K.S., Dewhurst, R.J., Merry, R.J., Scollan, N.D., 2006. J. Anim. Sci. 84, 3061 -3070.

Lee, M.R.F., Theobald, V.J., Tweed, J.K.S., Winters, A.L., Scollan, N.D., 2009. J. Dairy Sci. 92, 1136-1147.

Lee, M.R.F., Theodorou, M.K., Chow, T.T., Enser, M., Scollan, N.D., 2002. Proc. Brit. Nutr. Soc. 61, 103 A.

Lee, M.R.F., Tweed, J.K.S., Dewhurst, R.J., Scollan, N.D., 2006. Anim. Sci. 82, 31-40.

Legay, F., 1989. PhD, Univ. Clermont-Ferrand, France, 231 p.

Leonardi, C., Bertics, S., Armentano, L.E., 2005. J. Dairy Sci. 88, 2820-2827.

Lock, A., Garnsworthy, P.C., 2002. Anim. Sci. 74, 163-176.

Loor, J.J., Ueda, K., Ferlay, A., Chilliard, Y., Doreau, M., 2004. J. Dairy Sci. 87, 2472-2485.

Lough, A.K., Anderson, L.J., 1973. Proc. Nutr. Soc. 32, 61A-62A.

Mackle, T.R., Kay, J.K., Auldist, M.J., McGibbon, A.K.H., Philpott, B.A., Baumgard, J.H., Bauman, D.E., 2003. J. Dairy Sci. 86, 644-652.

MacLeod, G.K., Wood, A.S., Yao, Y.T., 1972. J. Dairy Sci. 55, 446-453.

MacLeod, G.K., Yu, Y., Schaeffer, L.R., 1977. J. Dairy Sci. 60, 726-738.

Madison-Anderson, R.J., Schingoethe, D.J., Brouk, M.J., Baer, R.J., Lentsch, M.R., 1997. J. Dairy Sci. 80, 1329-1338.

Maiga, H.A., Schingoethe, D.J., Ludens, F.C., 1995. J. Dairy Sci. 78, 1122-1130.

Mandebvu, P., Ballard, C.S., Sniffen, C.J., Carter, M.P., Wolford, H.M., Tato, S., Yabuuchi, Y., Block, E., Palmquist, D.L., 2003.

Anim. Feed Sci. Technol. 108, 25-41.

Martin, C., Rouel, J., Jouany, J.P., Doreau, M., Chilliard, Y., 2008. J. Anim. Sci. 86, 2642-2650.

Martin, P.A., Thomas, P.C., 1988. J. Sci. Food Agric. 43, 145-154.

Mattos, W., Palmquist, D.L., 1974. J. Dairy Sci. 57, 1050-1054.

Mattsson, P., 1978. St. Lantbr.-kem. Lab. Medd. 49, 19 pp.

Mielke, C.D., Schingoethe, D.J., 1981. J. Dairy Sci. 64, 1579-1585.

Moller, P.D., 1988. Futterfette in der Tierernährung, R. Ziegelitz, ed., Biolinol, Hamburg, Germany, pp. 23-39.

Moorby, J.M., Lee, M.R.F., Davies, D.R., Kim, E.J., Nute, G.R., Ellis, N.M., Scollan, N.D., 2009. J. Dairy Sci. $92,1148-1160$.

Murphy, M., Udén, P., Palmquist, D.L., Wiktorsson, H., 1987. J. Dairy Sci. 70, 1572-1582.

Nielsen, T.S., Straarup, E.M., Vestergard, M., Sejrsen, K., 2006. Reprod. Nutr. Dev. 46, 699-712.

Noci, F., O’Kiely, P., Monahan, P.J., Stanton, C., Moloney, A.P., 2005. Meat Sci. 69, 509-518.

Nuernberg, K., Dannenberger, D., Nuernberg, G., Ender, K., Voigt, J., Scollan, N.D., Wood, J.D., Nute, G.R., Richardson, R.I., 2005. Livest. Prod. Sci. 94, 137-147.

O’Sullivan, A., O’Sullivan, K., Galvin, K., Moloney, A.P., Troy, D.J., Perry, J.P., 2002. J. Anim. Sci. 80, 1556-1563.

Peng, A.C., 1974. Lipids 9, 299-301.

Peng, A.C., 1982. J. Food Sci. 47, 1036-1037.

Perry, F.G., Macleod, G.K., 1968. J. Dairy Sci. 51, 1233-1238.

Petit, H.V., Dewhurst, R.J., Proulx, J.G., Khalid, M., Haresign, W., Twagiramungu, H., 2001. Can. J. Anim. Sci. 81, $263-271$.

Petit, H.V., Dewhurst, R.J., Scollan, N.D., Proulx, J.G., Khalid, M., Haresign, W., Twagiramungu, H., Mann, G.E., 2002. J. Dairy Sci. 85, 889-899.

Petit, H.V., Germiquet, C., Lebel, D., 2004. J. Dairy Sci. 87, 3889-3898.

Poulson, C.S., Dhiman, T.R., Ure, A.L., Cornforth, D., Olson, K.C., 2004. Livest. Prod. Sci. 91, 117-128.

Raes, K., De Smet, S., Balcaen, A., Claeys, E., Demeyer, D., 2003. Reprod. Nutr. Dev. 43, 331-345.

Rego, O.A., Alves, S.P., Antunes, L.M.S., Rosa, H.J.D., Alfaia, C.F.M., Prates, J.A.M., Cabrita, A.R.J., Fonseca, A.J.M., Bessa, R.J.B., 2009. J. Dairy Sci. 92, 4530-4540.

Rego, O.A., Rosa, H.J.D., Portugal, P., Cordeiro, R., Borba, A.E.S., Vouzela, C.M., Bessa, R.J.B., 2005. Livest. Prod. Sci. $95,27-33$. Rego, O.A., Rosa, H.J.D., Portugal, P.V., Franco, T., Vouzela, C.M., Borba, A.E.S., Bessa, R.J.B., 2005. Anim. Res. 54, $17-24$.

Ruppert, L.D., Drackley, J.K., Bremmer, D.R., Clark, J.H., 2003. J. Dairy Sci. 86, 593-609. 
Sackmann, J.R., Duckett, S.K., Gillis, M.H., Realini, C.E., Parks, A.H., Eggelston, R.B., 2003. J. Anim. Sci. 81, $3174-3181$. Schingoethe, D.J., Brouk, M.J., Lightfield, K.D., Baer, R.J., 1996. J. Dairy Sci. 79, 1244-1249.

Scholljegerdes, E., Kronberg, S., 2008. J. Anim. Sci. 88, 2310-2320.

Schroeder, G.F., Delahoy, J.E., Vidaurreta, I., Bargo, F., Gagliostro, G.A., Muller, L.D., 2003. J. Dairy Sci. 86, $3237-3248$.

Scollan, N.D., Dhanoa, M.S., Choi, N.J., Maeng, W.J., Enser, M., Wood, J.D., 2001. J. Agric. Sci. 136, 345-355.

Sharma, H.R., Ingalls, J.R., McKirdy, J.A., 1978. J. Dairy Sci. 61, 574-583.

Shingfield K.J, Reynolds, C.K., Lupoli, B., Toivonen, V., Yurawecz, M.P., Delmonte, P., Griinari, J.M., Grandison, A.S., Shingfield, K.J., Ahvenjärvi, S., Toivonen, V., Vanhatalo, A., Huhtanen, P., Griinari, J.M., 2008. Br. J. Nutr. 99, 979-983.

Shingfield, K.J., Ahvenjärvi, S., Toivonen, V., Ärolä, A., Nurmela, K.V.V., Huhtanen, P.J., Griinari, J.M., 2003. Anim. Sci. 77, 165-179.

Shingfield, K.J., Ahvenjärvi, S., Toivonen, V., Vanhatalo, A., Huhtanen, P.J., Griinari, J.M., 2008. Br. J. Nutr. 99, $971-983$.

Shingfield, K.J., Lee, M.R.F., Humphries, D.J., Scollan, N.D., Toivonen, V., Reynolds, C.K., Beever, D.E., 2010. Br. J. Nutr. 104, 56-66.

Shorland, F.B., 1961. J. Sci. Food Agric. 12, 39-43.

Steele, W., 1985. J. Dairy Sci. 68, 1409-1415.

Stegeman, G.A., Casper, D.P., Schingoethe, D.J., Baer, R.J., 1992. J. Dairy Sci. 75, 1936-1945.

Steinshamn, H., Thuen, E., 2008. Livest. Sci. 119, 202-215.

Steinshamn, H., Thuen, E., Brenøe, U.T., 2006. In: Helgadottir A., Potsch E.M. Quality legume-based forage systems for contrasting environments, COST Final Meeting, Raumberg, Austria, pp. 153-156.

Storry, J.E., Hall, A.J., Johnson, V.W., 1971. J. Dairy Res. 38, 73-77.

Storry, J.E., Hall, A.J., Johnson, V.W., 1973. J. Dairy Res. 40, 293-299.

Sutton, J.D., Story, J.E., Nicholson, J.W.G., 1970. J. Dairy Res. 37, 97-105.

Tesfa, A.T., Touri, M.R., Syrjala-Quist, L., 1992. World Rev. Anim. Prod. 27, 34-40.

Vicente, G.R., Shelford, J.A., Peterson, T.G., Krishnamurti, C.R., 1984. Can. J. Anim. Sci. 64, 81-91.

Ward, A.T., Wittenberg, K.M., Froebe, H.M., Przybylski, R., Malcolmson, L., 2003. J. Dairy Sci. 86, 1742-1750.

Weenink, R.O., 1961. J. Sci. Food Agric. 12, 34-38.

White, B.G., Ingalls, J.R., Sharma, H.R., 1987. Can. J. Anim. Sci. 67, 437-465.

Whitlock, L.A., Schingoethe, D.J., Hippen, A.R., Kalscheur, K.F., Baer, R.J., Ramaswamy, N., Kasperson, K.M., 2002. J. Dairy Sci. $85,234-243$.

Whitlock, L.A., Schingoethe, D.J., Hippen, A.R., Kalscheur, K.F., AbuGhazaleh, A.A., 2003. J. Dairy Sci. 86, $2428-2437$.

Wiesen, B., Kincaid, R.L., Hillers, J.K., Harrison, J.H., 1990. J. Dairy Sci. 73, 3555-3562.

Wonsil, B.J., Herbein, J.H., Watkins, B.A., 1994. J. Nutr. 124, 556-565.

\section{References}

Alves, S.P., Cabrita, A.R.J., Jeronimo, E., Bessa, R.J.B., Fonseca, A.J.M., 2011. Effect of ensiling and silage additives on fatty acid composition of ryegrass and corn experimental silages. J. Anim. Sci. 89, 2537-2545.

Arvidsson, K., Gustavsson, A.M., Martinsson, K., 2008a. The effect of N-fertilization on fatty acid composition in forage plants. In: Multifunctional Grasslands in a Changing World, Volume II: XXI International Grassland Congress and VIII International Rangeland Congress, Hohhot, China, 29 June-5 July 2008, p. 671.

Arvidsson, K., Gustavsson, A.-M., Martinsson, K., 2008b. Effect of conservation method on fatty acid composition in silage. In: Hopkins, A., Gustafsson, T., Bertilsson, J., Dalin, G., Nilsdotter-Linde, N., Spörndly, E. (Eds.), 22nd General Meeting of the European Grassland Federation. European Grassland Federation, Uppsala, Sweden, pp. 654-656.

Arvidsson, K., Gustavsson, A.-M., Martinsson, K., 2009. Effects of conservation method on fatty acid composition of silage. Anim. Feed Sci. Technol. 148, $241-252$.

Baumont, R., Arrigo, Y., Niderkorn, V., 2011. Changes in plants during conservation and the consequences on their nutritional value for ruminants. Fourrages 205, 35-46 (in French, Eng. Abstr.).

Boufaied, H., Chouinard, P.Y., Tremblay, G.F., Petit, H.V., Michaud, R., Belanger, G., 2003. Fatty acids in forages. I. Factors affecting concentrations. Can. J. Anim. Sci. 83, 501-511.

Buccioni, A., Decandia, M., Minieri, S., Molle, G., Cabiddu, A., 2012. Lipid metabolism in the rumen: new insights on lipolysis and biohydrogenation with an emphasis on the role of endogenous plant factors. Anim. Feed Sci. Technol. 174, 1-25.

Casper, D.P., Schingoethe, D.J., Eisenbeisz, W.A., 1990. Response of early lactation cows to diets that vary in ruminal degradability of carbohydrates and amount of fat. J. Dairy Sci. 73, 425-444.

Casper, D.P., Schingoethe, D.J., Middaugh, R.P., Baer, R.J., 1988. Lactational responses of dairy cows to diets containing regular and high oleic acid sunflower seeds. J. Dairy Sci. 71, 1267-1274.

Chichlowski, M.W., Schroeder, J.W., Park, C.S., Keller, W.L., Schimek, D.E., 2005. Altering the fatty acids in milk fat by including canola seed in dairy cattle diets. J. Dairy Sci. 88, 3084-3094.

Chilliard, Y., Glasser, F., Ferlay, A., Bernard, L., Rouel, J., Doreau, M., 2007. Diet, rumen biohydrogenation and nutritional quality of cow and goat milk fat. Eur. J. Lipid Sci. Technol. 109, 828-855.

Dewhurst, R.J., King, P.J., 1998. Effects of extended wilting, shading and chemical additives on the fatty acids in laboratory grass silages. Grass For. Sci. 53, 219-224.

Dewhurst, R.J., Scollan, N.D., Youell, S.J., Tweed, J.K.S., Humphreys, M.O., 2001. Influence of species, cutting date and cutting interval on the fatty acid composition of grasses. Grass For. Sci. 56, 68-74.

Dewhurst, R.J., Shingfield, K.J., Lee, M.R.F., Scollan, N.D., 2006. Increasing the concentrations of beneficial polyunsaturated fatty acids in milk produced by dairy cows in high-forage systems. Anim. Feed Sci. Technol. 131, 168-206.

Dhiman, T.R., Helmink, E.D., McMahon, D.J., Fife, R.L., Pariza, M.W., 1999. Conjugated linoleic acid content of milk and cheese from cows fed extruded oilseeds. J. Dairy Sci. 82, 412-419.

Doreau, M., Rearte, D., Portelli, J., Peyraud, J.L., 2007. Fatty acid ruminal metabolism and digestibility in cows fed perennial ryegrass. Eur. J. Lipid Sci. Technol. 109, 790-798. 
Elgersma, A., Ellen, G., Horst, H.v., Muuse, d., Boer, B.G., Tamminga, H.S., 2003. Comparison of the fatty acid composition of fresh and ensiled perennial ryegrass (Lolium perenne L.), affected by cultivar and regrowth interval. Anim. Feed Sci. Technol. 108, 191-205.

Elgersma, A., Maudet, P., Witkowska, I.M., Wever, A.C., 2005. Effects of nitrogen fertilisation and regrowth period on fatty acid concentrations in perennial ryegrass (Lolium perenne L.). Ann. Appl. Biol. 147, 145-152.

Farruggia, A., Martin, B., Baumont, R., Prache, S., Doreau, M., Hoste, H., Durand, D., 2008. Is floristic diversity of permanent pastures important for ruminants and animal products? INRA Prod. Anim. 21, 181-200 (in French, Eng. Abstr.).

Fievez, V., Vlaeminck, B., Raes, K., Chow, T.T., De Smets, D., Demeyer, D., Bruinenberg, M.H., 2002. Dietary and milk fatty acid composition in relation to the use of forages from semi-natural grasslands. Multi-function grasslands: quality forages, animal products and landscapes. In: Proceedings of the 19th General Meeting of the European Grassland Federation, La Rochelle, France, 27-30 May 2002, European Grassland Federation, pp. $558-559$.

Folch, J., Lees, M., Sloane-Stanley, G.H., 1957. A simple method for the isolation and purification of total lipids from animal tissues. J. Biol. Chem. 226, 497-509.

Glasser, F., Ferlay, A., Chilliard, Y., 2008a. Oilseed lipid supplements and fatty acid composition of cow milk: a meta-analysis. J. Dairy Sci. 91, $4687-4703$.

Glasser, F., Schmidely, P., Sauvant, D., Doreau, M., 2008b. Digestion of fatty acids in ruminants: a meta-analysis of flows and variation factors. 2. C18 fatty acids. Animal 2, 691-704.

Khan, N.A., Cone, J.W., Fievez, V., Hendriks, W.H., 2012. Causes of variation in fatty acid content and composition in grass and maize silages. Anim. Feed Sci. Technol. 174, 36-45.

Lourenço, M., Van Ranst, G., De Smet, S., Raes, K., Fievez, V., 2007. Effect of grazing pastures with different botanical composition by lambs on rumen fatty acid metabolism and fatty acid pattern of longissimus muscle and subcutaneous fat. Animal 1,537-545.

Molloy, L.F., Giltrap, D.J., Collie, T.W., Metson, A.J., 1975. Degradation of higher fatty acids in perennial ryegrass and white clover following drying and storage. J. Sci. Food Agric. 25, 595-606

Morel, I., Wyss, U., Collomb, M., 2006a. Influence of the botanical composition of grass or silage on milk composition. Rev. Suisse Agric. 38, 115-120.

Morel, I., Wyss, U., Collomb, M., Butikofer, U., 2006b. Influence of the botanical composition of grass or hay on milk composition. Rev. Suisse Agric. 38, 9-15.

Palladino, R.A., O’Donovan, M., Kennedy, E., Murphy, J.J., Boland, T.M., Kenny, D.A., 2009. Fatty acid composition and nutritive value of twelve cultivars of perennial ryegrass. Grass For. Sci. 64, 219-226.

Palmquist, D.L., Jenkins, T.C., 2003. Challenges with fats and fatty acid methods J. Anim. Sci. 81, 3250-3254.

SAS Institute, 2008. SAS/STAT User's Guide Version 9.2. SAS Institute Inc., Cary, NC, USA.

Sauvant, D., Perez, J.-M., Tran, G. (Eds.), 2004. Tables of Composition and Nutritive Value of Feedstuffs for Farm Animals. Wageningen Academic Publishers, The Netherlands and Inra Editions, Paris, France.

Sauvant, D., Schmidely, P., Daudin, J.J., St-Pierre, N.R., 2008. Meta-analyses of experimental data in animal nutrition. Animal 2, $1203-1214$.

Schmidely, P., Glasser, F., Doreau, M., Sauvant, D., 2008. Digestion of fatty acids in ruminants: a meta-analysis of flows and variation factors. 1. Total fatty acids. Animal 2, 677-690.

Shingfield, K.J., Salo-Väänänen, P., Pahkala, E., Toivonen, V., Jaakkola, S., Piironen, V., Huhtanen, P., 2005. Effect of forage conservation method, concentrate level and propylene glycol on the fatty acid composition and vitamin content of cows' milk. J. Dairy Res. 72, 349-361.

Steinshamn, H., Bleken, M.A., Langeland, A., Thuen, E., 2006. Influence of clover species in mixtures with grasses on fatty acid composition of mixtures. In: Lloveras, J., Gonzalez-Rodriguez, A., Vazquez-Yanez, O., Pineiro, J., Santamaria, O., Olea, L., Poblaciones, M.J. (Eds.), 21st General Meeting of the European Grassland Federation. European Grassland Federation, Badajoz, Spain, pp. 351-353.

Steinshamn, H., Thuen, E., 2008. White or red clover-grass silage in organic dairy milk production: grassland productivity and milk production responses with different levels of concentrate. Livest. Sci. 119, 202-215.

Sukhija, P.S., Palmquist, D.L., 1988. Rapid method for determination of total fatty acid content and composition of feedstuffs and feces. J. Agric. Food Chem. 36, 1202-1206.

Tukey, J.W., 1977. Exploratory Data Analysis. Addison-Wesley, MA, USA.

Van Ranst, G., Fievez, V., De Riek, J., Van Bockstaele, E., 2009. Influence of ensiling forages at different dry matters and silage additives on lipid metabolism and fatty acid composition. Anim. Feed Sci. Technol. 150, 62-74.

Warren, H.E., Tweed, J.K.S., Youell, S.J., Dewhurst, R.J., Lee, M.R.F., Scollan, N.D., 2002. Effect of ensiling on the fatty acid composition of the resultant silage. Multi-function grasslands: quality forages, animal products and landscapes. In: Proceedings of the 19th General Meeting of the European Grassland Federation, La Rochelle, France, 27-30 May 2002, pp. 100-101.

Wiesen, B., Kincaid, R.L., Hillers, J.K., Harrison, J.H., 1990. The use of rapeseed screenings in diets for lactating cows and subsequent effects on milk yield and composition. J. Dairy Sci. 73, 3555-3562.

Witkowska, I., Wever, C., Gort, G., Elgersma, A., 2008. Effects of nitrogen rate and regrowth interval on perennial ryegrass fatty acid content during the growing season. Agron. J. 100, 1371-1379. 